\title{
Review \\ Mycobacteriophages as Potential Therapeutic Agents against Drug-Resistant Tuberculosis
}

\author{
Anna Allué-Guardia ${ }^{1, *}$, Rajagopalan Saranathan ${ }^{2}$, John Chan ${ }^{2}$ and Jordi B. Torrelles ${ }^{1, *}$ (D) \\ 1 Population Health Program, Tuberculosis Group, Texas Biomedical Research Institute, San Antonio, TX 78227, USA \\ 2 Department of Microbiology and Immunology, Albert Einstein College of Medicine, New York, NY 10461, USA; \\ saranathan.rajagopalan@einsteinmed.org (R.S.); john.chan@einsteinmed.org (J.C.) \\ * Correspondence: aallueguardia@txbiomed.org (A.A.-G.); jtorrelles@txbiomed.org (J.B.T.)
}

Citation: Allué-Guardia, A.;

Saranathan, R.; Chan, J.; Torrelles, J.B.

Mycobacteriophages as Potential

Therapeutic Agents against

Drug-Resistant Tuberculosis. Int. J.

Mol. Sci. 2021, 22, 735. https://

doi.org/10.3390/ijms22020735

Received: 7 December 2020

Accepted: 8 January 2021

Published: 13 January 2021

Publisher's Note: MDPI stays neutral with regard to jurisdictional clai$\mathrm{ms}$ in published maps and institutional affiliations.

Copyright: $(\odot 2021$ by the authors. Licensee MDPI, Basel, Switzerland. This article is an open access article distributed under the terms and conditions of the Creative Commons Attribution (CC BY) license (https:// creativecommons.org/licenses/by/ $4.0 /)$.

\begin{abstract}
The current emergence of multi-, extensively-, extremely-, and total-drug resistant strains of Mycobacterium tuberculosis poses a major health, social, and economic threat, and stresses the need to develop new therapeutic strategies. The notion of phage therapy against bacteria has been around for more than a century and, although its implementation was abandoned after the introduction of drugs, it is now making a comeback and gaining renewed interest in Western medicine as an alternative to treat drug-resistant pathogens. Mycobacteriophages are genetically diverse viruses that specifically infect mycobacterial hosts, including members of the M. tuberculosis complex. This review describes general features of mycobacteriophages and their mechanisms of killing M. tuberculosis, as well as their advantages and limitations as therapeutic and prophylactic agents against drug-resistant M. tuberculosis strains. This review also discusses the role of human lung micro-environments in shaping the availability of mycobacteriophage receptors on the M. tuberculosis cell envelope surface, the risk of potential development of bacterial resistance to mycobacteriophages, and the interactions with the mammalian host immune system. Finally, it summarizes the knowledge gaps and defines key questions to be addressed regarding the clinical application of phage therapy for the treatment of drug-resistant tuberculosis.
\end{abstract}

Keywords: Mycobacterium tuberculosis; drug-resistance; mycobacteriophages; phage therapy; lung mucosa

\section{Introduction}

Tuberculosis (TB) is the leading cause of mortality worldwide due to a single infectious disease, with an estimate of $\sim 1.4$ million attributed deaths in 2019 [1]. It is caused by the airborne pathogen Mycobacterium tuberculosis (M. tuberculosis), which upon inhalation is deposited in the lung alveolar space. In that environment, $M$. tuberculosis comes in close contact with soluble components of the human alveolar lining fluid (ALF) prior to and following its encounter with alveolar resident and compartment cells [2,3]. After infection of alveolar cells such as alveolar macrophages (AMs), a host immune response is mounted to control the infection driving clearance, active TB disease or, in the majority of the cases, latent $M$. tuberculosis infection, which is controlled and maintained in a complex cellular structure called granuloma.

When active TB disease is developed, the standard treatment consists of a 6-month regimen using a combination of four first-line drugs (isoniazid, rifampicin, ethambutol, and pyrazinamide) that, although very efficient, can promote the emergence of resistance in the absence of sufficient healthcare infrastructure and patient poor adherence to therapy [4]. As a direct consequence, in the past two decades, multi (MDR), extensively (XDR), extremely (XXDR), and total (TDR) drug-resistant M. tuberculosis strains have emerged worldwide as a threat to public health and TB control, especially in TB endemic areas [5-7]. MDR strains are defined as resistant to at least the two first-line drugs isoniazid and rifampicin, whereas XDR, first reported in 2006 in South Africa, are resistant to isoniazid and rifampicin plus any fluoroquinolone, and at least one of the three injectable second-line drugs (amikacin, 
kanamycin, or capreomycin) [8]. Treatment of drug-resistant $M$. tuberculosis strains is lengthy (up to two years) and costly (worldwide the median cost per person treated for TB in 2019 was US\$ 860 for drug-susceptible TB vs. US $\$ 5,659$ for MDR-TB) [1]. The latest treatment outcome data in the WHO 2020 TB report show success rates of $85 \%$ for susceptible TB, while only $57 \%$ for MDR-TB [1]. XXDR M. tuberculosis strains are resistant to all first and second-line drugs [9]. The boundaries between XXDR and TDR have not been fully defined [10], and even though TDR is a term that has not been recognized by the WHO [11], M. tuberculosis strains resistant to all tested antibiotics, including some that are still in the discovery pipeline, have been identified in India, Iran, Italy, and South Africa, and designated as "Totally drug-resistant" [6,7]. This makes XXDR and TDR M. tuberculosis strains virtually incurable [12].

With the global burden of MDR-TB increasing at an annual rate of $>20 \%$ in the past few years, it is estimated that drug-resistant TB will kill 75 million people and cost the global economy $\$ 16.7$ trillion over the next 35 years, stressing the need to develop new drugs and/or alternative anti-TB therapies $[13,14]$. Currently, 22 drugs for the treatment of drug-susceptible TB, MDR-TB or latent TB are in Phase I, II or III trials, including 13 new compounds and six repurposed drugs, among others [1]. Most of the current treatments target the $M$. tuberculosis cell envelope, a complex structure comprised mainly of carbohydrates and lipids. However, little is known about the cell envelope composition of drug-resistant $M$. tuberculosis strains and their adaptation to the lung environment, which makes it challenging to develop new effective drug regimens [15]. Such strains bring us back to the pre-antibiotic era and emphasize the urgent need to develop alternative strategies to combat the disease.

The idea of using bacteriophages (virus that infect bacteria) to treat infectious diseases was first introduced at the beginning of the 20th century, shortly after Felix d'Herelle described the appearance of small, clear areas (later called plaques) in agar cultures of Shigella strains incubated with fecal filtrates from dysentery patients, which he proposed were caused by virus capable of "eating" bacteria or bacteriophages (derived from "bacteria" and the Greek $\varphi \alpha \gamma \varepsilon \tilde{\imath} v$ or phagein, "to eat") [16,17]. During the 1920's, 30's and 40 's bacteriophages were commercially produced in several countries for the treatment or prophylaxis of several diseases such as dysentery, cholera, skin lesions or respiratory tract infections, among others [18-20]. However, at the time, the efficacy and safety of commercial phage preparations was questionable, not always reproducible, and the lack of detailed information on phage titers, host range, control groups, and experimental design in clinical trials promoted a growing skepticism towards phage therapy in the scientific community $[17,21]$. As a result, and with the introduction of penicillin and other antibiotics in the 1940's, the use of phage therapy was abandoned in Western countries. However not in the former Soviet Union, where intensive research is still being conducted at the Eliava Institute of Bacteriophage in Tbilisi (Georgia), and phage cocktails are currently approved for the treatment and/or prophylaxis of several diseases [22-26].

Even though the notion of phage therapy has been around for nearly a century, it is still considered an experimental treatment in Western countries and has not been approved for human use yet, in part due to non-existing phage therapy regulations and the lack of safe and well-described phage preparations [27-29]. In addition, the fact that phage therapy is conceived as personalized medicine presents extra challenges in the regulatory pipeline. In the US, the use of phages is only approved for the decontamination of food, plant-based and livestock products, or surfaces [21,30-34]. However, the Food and Drug Administration (FDA) has recently approved the new Center for Innovative Phage Applications and Therapeutics (IPATH) to use phage therapy as an experimental treatment through the Emergency Investigational New Drug scheme [28], focused on cases of serious or life-threatening conditions, when no satisfactory alternative therapy is available and the patient cannot receive treatment through any existing approved clinical trial. It is expected that initiatives like this will generate supporting data for phage therapy, gaining the trust of clinicians and researchers, for implementation in the near future. With the 
worldwide emergence of multidrug-resistant strains for most bacterial diseases, including $\mathrm{TB}$, antibiotics are becoming ineffective, with only a few new drugs in the antibiotic pipeline expected to be available in the next few years [35]. Thanks to vast advancements and a better understanding on phage biology and genomics over these past decades, as well as the development of new molecular biology tools for the study of bacteriophages and their interactions within the human body, we have now the framework to conduct exhaustive phage therapy studies, which opens the avenue for the potential use of phages as an alternative therapy when antibiotic treatment is not possible. As a consequence, these past few years have seen a renewed interest in the use of bacteriophages to treat multidrug-resistant bacteria, as well as chronic and persistent infections [21,36-40], with some experimental studies being conducted in the TB field. In this context, phages were successfully used to treat a patient with disseminated multidrug-resistant Mycobacterium abscessus [37].

This review will focus on what we know about mycobacteriophages and their applications to kill M. tuberculosis, as well as recently developed tools for bacteriophage engineering, with a particular emphasis in the current and future status on the use of mycobacteriophages to treat drug-resistant $\mathrm{TB}$.

\section{Mycobacteriophages}

\subsection{General Features}

Mycobacteriophages are virus that specifically infect mycobacterial hosts, first isolated in the 1940s [41]. Upon isolation, one of their initial applications was their use for the typing of clinical Mycobacterium spp. (Table 1). The fact that some phages have narrowed host range specificities, e.g., infecting particular mycobacterial species and even strains, allowed the use of defined mycobacteriophage sets with pre-determined host specificities to identify newly isolated mycobacterial strains $[42,43]$. However, with the development of new molecular tools, phage typing was replaced by DNA-based methods [43]. The following years, several characterization studies were conducted [44-48], which would establish the framework for the subsequent studies on mycobacteriophage applications in M. tuberculosis genetics $[49,50]$. In the 1980's, the description of shuttle phasmids as DNA transporters between $E$. coli plasmids and mycobacteriophages paved the way for recombinant DNA research in mycobacteria [51], and contributed to the subsequent development of mycobacteriophage-based methods for the genetic manipulation of mycobacterial DNA. Since then, mycobacteriophages have been the key in development of genetic tools to engineer mycobacteria [52], including transduction of chromosomal markers and transposons [53], introduction of point mutations [54], the construction of $M$. tuberculosis deletion mutants [55-57], and/or the introduction of immunity-based selection markers in mycobacterial hosts [58] (Table 1). Reporter mycobacteriophages have been also constructed through both "recombineering" (genetic engineering by phage recombination) and shuttle phasmid approaches, and used for TB diagnostic applications to assess active disease by determining the presence of viable M. tuberculosis bacilli, drug susceptibility or treatment efficacy [59-61] (Table 1). In this regard, luciferase reporter phages (LRPs) carrying the firefly luciferase gene (fflux) were first engineered in the 1990s [61] using different mycobacteriophages such as L5, D29, Che12 or TM4 [62,63], and have been improved since then by using the nanoluciferase (Nluc) reporter enzyme [64]. Further, fluoromycobacteriophages carrying the green fluorescent protein gene $(g f p)$ cassette were developed in 2009 [65] and used as a fast, highly specific and sensitive method for the detection of $M$. tuberculosis drug-resistant populations by measuring fluorescence emitted by GFP-expressing bacilli after phage infection [66-69]. Later, a dual-reporter mycobacteriophage ( $\left.\Phi^{2} \mathrm{DRMs}\right)$ was constructed by expressing GFP (mVenus) constitutively after $M$. tuberculosis infection and tdTomato (red fluorescent protein) through the dnaK promoter, which is specifically upregulated in persisters, in order to identify and quantitate $M$. tuberculosis persister cells after antibiotic treatment [70]. Mycobacteriophages could also be used as potential prophylactic and/or therapeutic agents (Table 1), applications that will be further discussed later in this review. 
Table 1. Applications of mycobacteriophages in TB.

\begin{tabular}{|c|c|}
\hline Applications & Notes \\
\hline Typing of clinical Mycobacterium isolates & $\begin{array}{l}\text { - Use of pre-defined host-specific mycobacteriophage sets to identify new } \\
\text { M. tuberculosis isolates. }\end{array}$ \\
\hline TB diagnostics & $\begin{array}{l}\text { - Use of reporter phages (e.g., LRP, } \Phi^{2} \mathrm{DRMs} \text {, etc) to determine the presence } \\
\text { of viable bacilli (active disease), } M \text {. tuberculosis drug susceptibility, and TB } \\
\text { treatment efficacy (e.g., identifying presence of persister bacilli). }\end{array}$ \\
\hline Mycobacterial genomic tools & $\begin{array}{l}\text { - Use for mycobacterial genetic manipulation including: gene exchange, } \\
\text { allelic exchange, recombination and transduction of chromosomal } \\
\text { markers, point mutations, transposons and insertions to generate } M \text {. } \\
\text { tuberculosis mutants. } \\
\text { Use to introduce immunity-based selection markers in mycobacterial } \\
\text { hosts (immunity to superinfection). }\end{array}$ \\
\hline Prophylaxis and therapeutics & $\begin{array}{l}\text { - Use of whole phages or mycobacteriophage-derived lytic enzymes to } \\
\text { efficiently lyse and eliminate mycobacterial hosts. } \\
\text { - Use as combined synergistic therapy: mycobacteriophages/endolysins + } \\
\text { anti-TB drugs. }\end{array}$ \\
\hline
\end{tabular}

With the advancement of new sequencing technologies during late 20th century, the first complete genome of mycobacteriophages were sequenced [50], providing better insight into their genetics and diversity. Till date, 11,468 mycobacteriophages have been isolated and 1971 mycobacteriophage genomes sequenced [71,72] (as of 5 January 2021). These phages have been mainly isolated and characterized from the environment, using non-pathogenic and fast-growing mycobacterial hosts such as M. smegmatis [73,74].

All described mycobacteriophages to date belong to the Caudoviridae type, characterized by an icosahedral head with double-stranded DNA (dsDNA) and a tail [75,76], and specifically to the Myoviridae (with contractile tail) and Siphoviridae (non-contractile tail) families, the later containing $>90 \%$ of the mycobacteriophages described [77]. As for their genomic diversity, mycobacteriophages constitute architectural mosaics, evidenced by the presence of segments with distinctive evolutionary histories acquired or lost through different recombination events [78-80]. Still, most mycobacteriophages share a similar overall genome architecture, with structural and assembly genes ( $50 \%$ of the genome) at the left end of the genome [81], followed by a bacterial lysis system and genes responsible for the lytic/lysogenic life cycles, including integration or partitioning systems [82]. Other non-structural genes are tRNA and tmRNA, potentially involved in gene expression $[80,83]$, mobile genetic elements (MGEs) [84,85], and several other genes of unknown function [55]. The latter do not seem to be required directly for phage replication, but instead might modulate bacteria-phage and/or phage-phage dynamic interactions [86,87]. Indeed, temperate mycobacteriophages, which can either undergo lytic or lysogenic cycle (Figure 1A), play important roles in these interactions both during lysogeny by prophage-mediated defense systems against the attack of other phages, and by superinfection exclusion during lytic replication, reviewed in detail elsewhere [77,88-90]. 


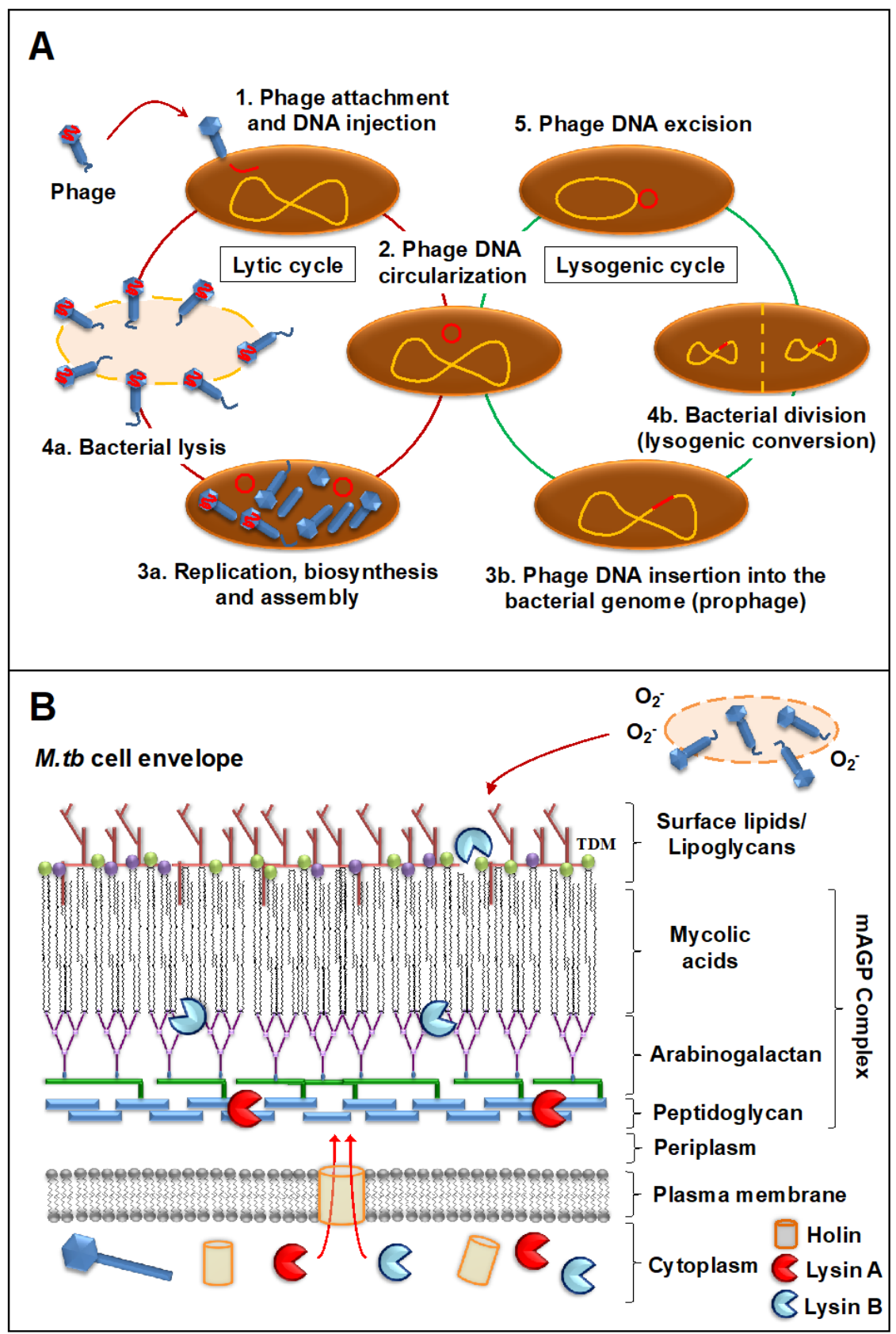

Figure 1. Infection of M. tuberculosis by mycobacteriophages. (A) Steps during mycobacteriophage infection: (1) The phage attaches to $M$. tuberculosis through specific receptors and injects its DNA (red); (2) Phage DNA circularizes inside the M. tuberculosis bacillus; then, specific environmental cues will determine if the phage undergoes a lytic or a lysogenic cycle. If the lytic cycle is induced: (3a) New phage DNA and viral proteins are synthesized and assembled into new viral particles and; (4a) Viral particles will be released after the lysis of the M. tuberculosis bacillus. If the lysogenic cycle is induced: ( $3 \mathrm{~b})$ The phage genome is integrated into the $M$. tuberculosis chromosome, becoming a prophage; (4b) The prophage will replicate along the $M$. tuberculosis genome and will be transmitted to the progeny that will acquire new properties encoded in the prophage (lysogenic conversion); (6) Under certain triggers, the prophage DNA will be excisioned from the bacterial chromosome and the lytic cycle induced (3a-4a). (B) Most mycobacteriophages rely on endolysin-holin systems to kill their hosts. Holins act as membrane proteins to help translocate the lysins to reach their targets: Lysin A degrades the peptidoglycan layer, whereas Lysin B cleaves the ester bonds between mycolic acids and the arabinogalactan in the mycolyl-arabinogalactan-peptidoglycan (mAGP) complex, disrupting the M. tuberculosis cell wall core (mAGP). Lysin B is also known to degrade trehalose dimycolates (TDMs) in the outer layer. Although lysis is the primary mycobacteriophage mechanism for bacterial death, secondary mechanisms such as the release of superoxide $\left(\mathrm{O}_{2}{ }^{-}\right)$radicals from lysed bacilli might also contribute in the elimination of M. tuberculosis. 
Based on their overall nucleotide similarity, mycobacteriophages are grouped in different clusters and sub-clusters, where phages from the same cluster share $>50 \%$ of their genomic DNA or $>35 \%$ of their genes [77]. Currently, there are 29 defined mycobacteriophage clusters [ $\mathrm{A}$ to $\mathrm{Z}, \mathrm{AA}, \mathrm{AB}$, and $\mathrm{AC}$ ], being $\mathrm{A}$ the largest cluster; and 16 singletons, which are not genetically related to any of the other clusters and constitute separate groups by themselves. Twelve clusters are further divided into sub-clusters: A1 to A14 and A16 to A20 (A15 phages only infect Gordonia strains), B1 to B13, C1 and C2, D1 and D2, F1 to F5, G1 to G5, H1 and H2, I1 and I2, K1 to K7, L1 to L4, M1 to M3, and P1 to P6. Sequenced mycobacteriophages have been mostly isolated in M. smegmatis, although some of them are also reported to infect other mycobacterial species such as $M$. abscessus, M. aichiense, $M$. aurum, M. avium, M. phlei, and M. tuberculosis; including 17 different strains among these species [72]. Phages are constantly assigned to these groups based on sequence similarity and clusters and sub-clusters created as new phage sequences are being discovered [91-93]. These mycobacteriophage clusters are based on sequence similarity, indicative of their mosaic architecture, which does not necessarily correlate with their biological and/or evolutionary significance.

\subsection{Mode of Action against Mycobacterial Hosts}

As phages that infect mycobacterial hosts, mycobacteriophages are equipped with the machinery to efficiently lyse mycobacteria. That includes encoding for lysins or endolysins (LysA), enzymes with the ability to cleave the peptidoglycan (PG) layer present in the mycobacterial cell envelope (Figure 1B). All mycobacteriophages, including the temperate ones, encode proteins that act as endolysins. This is the case of phage Che12, capable of infecting and lysogenizing $M$. tuberculosis [94]. These endolysins seem to be pretty diverse and modular, but most of them are composed of three domains: a C-terminal domain associated with binding to specific substrates in the bacterial cell envelope, and two catalytic domains (central and N-terminal domains) predicted to target most of the peptidoglycan bonds [95-98]. Further, most mycobacteriophages rely on endolysin-holin systems to degrade the PG layer. While endolysins target the integrity of the M. tuberculosis cell envelope, holins are membrane proteins that help translocate endolysins to reach their target or trigger the activation of the enzymes at a defined time [95] (Figure 1B). Indeed, recent studies of mycobacteriophage D29 physiology show that while holin is dispensable for phage viability, it is essential for a timely and efficient host cell lysis and phage progeny propagation [99]. LysA holin-independent lysis mechanisms are also described in some mycobacteriophages [100]. However, the M. tuberculosis cell envelope is a much more complex and dynamic structure compared to gram-negative and -positive pathogens, featuring a thick mycolyl-arabinogalactan-peptidoglycan complex core (mAGP) involved in virulence and persistence [101]. To be able to go past this natural barrier, most mycobacteriophages encode another enzyme located downstream of lys A, named Lysin B (LysB), an esterase that degrades this complex cell envelope structure by cleaving the ester bonds between the mycolic acids and the arabinogalactan [102,103]. LysB also degrades trehalose dimycolate (TDM), a glycolipid that plays an important role in mycobacterial pathogenesis $[104,105]$ (Figure 1B). Recently, the antimicrobial activity of phage D29 LysB against M. ulcerans has been demonstrated in a mouse model, showing synergistic inhibitory effects with other antimycobacterial drugs in vivo and inducing an immune response by increasing the levels of pro-inflammatory cytokines IFN- $\gamma$ and TNF in the DLN (draining lymph node) [106]. Besides the lysis as a primary mechanism of mycobacterial death, other authors have suggested the existence of secondary mechanisms, such as the production of superoxide radicals by lysed cells, or the induction of programmed cell death by mycobacteriophages [107] (Figure 1B). Moreover, phages can stimulate increased phagocytosis of bacteria through the opsonization of bacterial cells [108], where the phage coats the bacteria and makes it more recognizable by macrophages and other innate immune cells.

Phage-derived lytic enzymes such as endolysins are being studied as potential antimicrobial agents to combat infections caused by different gram-negative and 
-positive pathogens [34,109], with progresses made optimizing lysins through bioengineering $[106,110,111]$. Indeed, a recent study describes the novel concept of "innolysins", an engineering approach that allows customization of endolysins by combining them with phage Receptor Binding Proteins (RBPs) to target specific bacteria [112]. Thus, "enzybiotic" is defined as a new and promising class of drugs derived from phage endolysins, characterized by a rapid mode-of-action, high specificity, and less probability to induce bacterial resistance when compared to traditional drugs [113]. Still, the use of mycobacteriophageencoded lysins to treat TB has major challenges, including the access of these lysins to the peptidoglycan layer through the thick M. tuberculosis cell envelope, which gets further complicated by the fact that drug-resistant $M$. tuberculosis are thought to have even more complex cell envelope than drug-susceptible strains [15]. Thus, it is critical to determine which mycobacteriophages are able to infect and specifically kill drug-resistant $M$. tuberculosis strains. Additionally, it is critical to fully understand the mechanisms by which mycobacteriophages dismantle mycobacterial cell envelope layers in order to design new strategies using them alone, in combination, or in synergistic combination with existing drugs [106,114]. Indeed, studies indicate that gp39, a novel gene of mycobacteriophage SWU1 with unknown function, can disrupt mycobacterial lipid metabolism increasing the cell envelope permeability, ultimately potentiating the efficacy of multiple drugs against M. smegmatis in vitro [115].

Several efforts are being conducted to identify novel mycobacteriophage proteins with antimicrobial activity [116,117]. For instance, a small peptide derived from mycobacteriophage Che12, conserved in many mycobacteriophages, showed mycobactericidal and immunoregulatory functions in a M. tuberculosis mouse model [118]. Even though the use of phage-derived products has the potential to treat drug-resistant $\mathrm{TB}$, there are some limitations when compared to the use of live mycobacteriophages such as these phage enzymes lack the capacity of self-replication at the site of the infection, they cannot adapt to the environment, and similar to drugs, the pathogen can adapt to select resistant clones, although it is not expected to be at a high rate [119]. Conversely, it is unknown if these enzymes are expressed in sufficient amounts by mycobacteriophages during the M. tuberculosis-host cell interplay.

\section{Phage Therapy to Treat Multidrug-Resistant TB}

Phage therapy was found to be successful against different pathogens such as Pseudomonas aeruginosa [120-124], Staphylococcus aureus [125], Klebsiella pneumoniae [126], Acinetobacter baumannii [127], Clostridium difficile [128], Enterococcus faecalis [129] or Escherichia coli $[130,131]$, among others $[21,132,133]$. Furthermore, in recent years, several animal and human studies have shown promising results in the treatment of diseases caused by diverse drug-resistant bacteria [21]. This is the case of a topical mono-phage preparation successfully used to treat 6 patients with diabetic foot ulcer infected with MDR S. aureus [134]. The first clinical trial (Phase I/II) conducted using an oral phage administration against chronic otitis caused by antibiotic-resistant P. aeruginosa, also resulted in bacterial load reduction with no adverse effects reported [135]. Further, when the efficacy of phage $\mathrm{pVp}-1$ was tested in a sepsis murine model to treat MDR V. parahaemolyticus, a reduction in mortality was observed using both intraperitoneal and oral routes of administration [136]. Not only phage therapy has proven to be successful against some MDR pathogens, but there is also evidence that phages might be capable of restoring drug sensitivity of such pathogens. In this regard, development of bacterial resistance to phage infection in MDR P. aeruginosa comes with an evolutionary trade-off: changes in the multidrug efflux pump outer membrane porin $\mathrm{M}(\mathrm{OprM})$, which acted as phage-binding receptor, led to decreased phage infectivity but increased sensitivity to different classes of drugs [137].

All these studies are proof-of-concept that it is feasible to use phage therapy to treat drug-resistant bacteria, including $M$. tuberculosis. So far, only a few bacteriophages have been investigated as potential therapeutic options to treat TB in different in vitro studies, 
including mycobacteriophages DS6A, TM4, D29, BTCU-1, SWU1 and Ms6 [reviewed in detail by [138]], with only two in vivo studies using the guinea pig model [139,140] showing promising results in the elimination of $M$. tuberculosis. However, to date, there is still limited data regarding the use of mycobacteriophages in the treatment of MDR-mycobacterial infections [37].

There are several general phage features that make mycobacteriophages suitable as therapeutic agents against drug-resistant TB [132,141]: (a) By nature, phages only infect and replicate inside their bacterial hosts without harming the human eukaryotic cells, and have the capacity to lyse and kill their hosts at the infection site [142]; (b) Their host range is mostly limited to Mycobacterium spp., which allows for the development of targeted therapies for specific $M$. tuberculosis strains with no apparent collateral damage to the human microbiota [143], representing one of the major advantages of phage therapy over the use of drugs; (c) Phages are the most abundant organisms in the biosphere $\left(10^{31}\right.$ viral particles estimated for the entire phage population $[144,145])$, isolated from multiple environments through common and well-established microbiology techniques [91], and easy to characterize using molecular biology tools [146]. New mycobacteriophages have been sequenced and characterized these past few years [73], indicating the existence of a great phage diversity [147], which could lead to the discovery of novel mechanisms to disrupt the M. tuberculosis cell envelope; (d) Phages are easy to engineer to contain suitable features for phage therapy; (e) Because phages have the ability to replicate inside the pathogen using the bacterial cell machinery to generate more viral particles, less number of doses are required when compared to drug treatments [143]. In this context, mathematical model for population dynamics showed that a single dose of phages is more effective than multiple doses of drugs to treat systemic infections caused by E. coli [148]; and lastly (f) Phages are easy to propagate at large-scale in an in vitro setting, significantly reducing the production costs when compared to drugs [132].

Nonetheless, there are still challenges to overcome before mycobacteriophages could be widely used to treat MDR-, XDR-, and XXDR-TB [149]. These are discussed below and summarized in Table 2.

\subsection{Mycobacteriophage Host Specificity}

In nature, bacteriophages present very diverse host specificities, and we can find those that infect different species within a genus or even strains from different taxonomically related genus (broad host range), whereas others only infect a particular bacterial species and/or strain (narrow host range). Mycobacteriophages belong to the latter, with their host range restricted to Mycobacterium and some other members of the Actinobacteria phylum $[150,151]$. Moreover, there are some mycobacteriophages that can only infect a particular species [152]. Most mycobacteriophages have been isolated using the non-pathogenic and fast-growing $M$. smegmatis as a host, and only a few of them have been tested and shown to also efficiently infect and lyse $M$. tuberculosis [150,151,153-155]. Evidence indicates a strong correlation between cluster designation, reflective of genomic variability, and host specificity $[77,156]$. Infectivity of $M$. tuberculosis is a feature that seems mainly restricted to cluster $\mathrm{K}$ and sub-clusters A2 and A3 mycobacteriophages [157], including the extensively studied TM4, L5, and D29. Members of others clusters do not infect $M$. tuberculosis or they infect at very low efficiencies. Specific infectivity of $M$. tuberculosis could be due to different factors [158] including abundance and status of the preferred bacterial host in the environment [159], bacterial host receptor nature and availability, or bacterial defense systems and phage-specific restriction/modification mechanisms, as suggested by the capacity of phage DS6A to form plaques exclusively on bacterial members of the M. tuberculosis complex [151]. Still, the genetic basis of bacterial host specificity remains largely unknown [156]. 
Table 2. Phage therapy challenges in drug-resistant TB treatment.

\begin{tabular}{|c|c|}
\hline Challenges and Limitations & Potential Solutions \\
\hline Host specificity & $\begin{array}{l}\text { - Global phage database screening. } \\
\text { Phage's host range expansion using directed phage evolution } \\
\text { and/or bioengineering. } \\
\text { Development of screening bioinformatics tools to identify targeted M.tb host } \\
\text { virulent factor epitopes (e.g., efflux pump). }\end{array}$ \\
\hline $\begin{array}{l}\text { Unknown impact of human ALF } \\
\text { on the } M . t b \text { cell envelope }\end{array}$ & $\begin{array}{l}\text { - Identify how the M.tb cell envelope adapts (changes) to the different } \\
\text { environments that encounters at different stages of infection [e.g., contact } \\
\text { with ALF, within the phagosome, extracellular, within granulomas or cavities, } \\
\text { or when being transmitted (in sputum)]. }\end{array}$ \\
\hline Phages access to intracellular $M . t b$ & $\begin{array}{l}\text { - Novel phage delivery systems [e.g., M. smegmatis (Trojan horse concept), } \\
\text { phage microencapsulation]. } \\
\text { Phage bioengineering to recognize well-defined macrophage receptors (the } \\
\text { mannose receptor or MR). }\end{array}$ \\
\hline M.tb resistance to phages & $\begin{array}{l}\text { - Use of different phage cocktails. } \\
\text { Phage-drug combined treatment (phage-drug synergy) in combination with } \\
\text { the mammalian host immune response. } \\
\text { - Phage sequential treatment. } \\
\text { - Phage personalized treatment. }\end{array}$ \\
\hline $\begin{array}{l}\text { Overactivation of the mammalian host } \\
\text { immune system and risk of anaphylaxis }\end{array}$ & $\begin{array}{l}\text { - } \quad \text { Optimize phage delivery routes. } \\
\text { - } \quad \text { Establish phage dosage and frequency. } \\
\text { - Maximize synergy between phages and the mammalian host immune system. }\end{array}$ \\
\hline Lack of phage therapy regulations & - $\quad$ Standardize global regulations for phage production (under GMP conditions). \\
\hline Phage cytotoxicity to the human host & $\begin{array}{l}\text { - Use of highly lytic phages that do not integrate into the M.tb genome. } \\
\text { - Targeted phage genetic bioengineering to remove potential phage virulent } \\
\text { factors to the mammalian host. } \\
\text { - Define function of unknown phage genes. }\end{array}$ \\
\hline
\end{tabular}

Mycobacteriophage specific host range could be considered as a double-edge sword in regards to potential applications in phage therapy: on one hand, phage specificity is required for successful clearance of a particular pathogen without affecting the overall human microbiome composition. On the other hand, it also represents a significant limitation, as this high specificity might create a bottleneck in terms of identifying potential phage candidates to efficiently kill $M$. tuberculosis. However the growing mycobacteriophage database [72] is proof that newly isolated mycobacteriophages are being sequenced and characterized frequently, showing a great degree of genome diversity that could potentially expand the host range possibilities of the existing phage pool [92,147]. Indeed, mycobacteriophages have the ability to switch or expand their host range frequently among different mycobacterial strains $[77,156]$. Such is the case of cluster $G$ phage mutants with single residue substitutions in their tail proteins that infect $M$. tuberculosis strains more efficiently [156]. The use of directed evolution is also being explored as a tool to increase the infectivity of mycobacteriophages under different experimental conditions [160].

Because the first interaction between mycobacteriophages- $M$. tuberculosis (phage adsorption) involves the attachment of the virion onto a bacilli, one can assume that recognition of $M$. tuberculosis cell envelope surface receptors by phage tail proteins and subsequent binding will likely determine phage-bacterial host specificity and infection efficiency, although not much is known about phage binding receptors on the M. tuberculosis cell envelope surface [161]. Only a few mycobacteriophage targets have been described for non-tuberculous mycobacteria: mycobacteriophage D4 interacts with the glycolipid mycoside C [162]; mycobacteriophage Phlei seems to target lyxose-containing molecules [163]; and mycobacteriophage I3 probably recognizes glycopeptidolipids (GPLs) on the mycobac- 
terial cell envelope [161]. Mycobacteriophages can also use more sophisticated two-step mechanisms, involving a reversible binding to a cell envelope saccharide, followed by an irreversible binding to a cell envelope emerging protein domain [164]. On the other hand, in the mycobacteriophage-mycobacteria recognition, several phage proteins were described. Minor tail proteins gp6 and lysin protein gp10 of phage L 5 and homolog proteins in D29 seem to recognize and bind to mycobacterial surface receptors [165]. In phage Rosebush, the gp42 protein is a tail component that assists in infection through hydrolytic degradation of sugar-containing molecules on the mycobacterial cell envelope surface [156]. In order to delineate molecular mechanisms of phage-M. tuberculosis interactions and their specificity and modulation, phage's tail interactions with $M$. tuberculosis bacterium attachment proteins and receptors need to be first defined. In this regard, a high-throughput approach based on transposon insertion sequencing, INSeq, was used to identify new phage receptors for multiple E. coli phages [166], with the potential of being used to characterize receptors in phages that infect other bacterial species, including $M$. tuberculosis. Identifying new receptors will provide insight to understand why only certain mycobacteriophage genomic types can infect members of the M. tuberculosis complex. In this regard, drug-resistant M. tuberculosis represent even a greater challenge than susceptible $M$. tuberculosis, as the former has a cell envelope composition that still remain largely unknown [15]. Recently, BSL-2 safe strains of MDR-M. tuberculosis that are triple auxotrophic (pantothenate, leucine and either arginine or methionine) have been developed for performing experiments in laboratories that do not have BSL-3 facilities [167]. These strains seem to be the most promising candidates to test mycobacteriophages for activity against MDR strains and also to understand their interactions.

Besides the natural ability of phages to expand their host range and to adapt to new bacterial hosts $[77,156]$, several studies have shown that phage specificity can be altered through genetic engineering of their RBPs [158]. Thus, by using different synthetic biology strategies, one could re-program RBPs specificity and consequently modify a phage's host range [168]. As finding phages for the M. tuberculosis complex and/or for a particular M. tuberculosis strain in the environment can prove to be time-consuming, synthetic biology approaches could represent a significant advancement in phage engineering, opening the avenue for the custom design of $M$. tuberculosis-specific mycobacteriophages for the treatment of drug-resistant TB. It would also allow to modify well-characterized lytic phages and expand its host range to efficiently infect $M$. tuberculosis. Through genetic engineering approaches one can also eliminate potential detrimental genes such as those encoding for toxins, antibiotic resistance and non-essential proteins of unknown function, as these can be transferred to the bacterial host by lysogenic conversion when a temperate phage DNA is integrated into the bacterial genome $[169,170]$. Because of the low lytic efficiency, the use of temperate bacteriophages for phage therapy is not recommended. Additionally, a recent study described the pathogenic role of temperate phage Pf in P. aeruginosa infections, wherein uptake of the virion by mammalian immune cells results in the production of phage RNA, triggering antiviral immunity through induction of type I interferon and suppressing bacterial clearance [171], which further supports the use of lytic instead of lysogenic phages.

Another key factor to consider in mycobacteriophage-M. tuberculosis interactions is the impact of the human lung environment in shaping the $M$. tuberculosis cell envelope. Upon infection, M. tuberculosis is deposited in the lung alveolar space where it comes in close contact with the lung mucosa. The lung mucosa is composed of surfactant lipids and an aqueous hypophase called alveolar lining fluid (or ALF). M. tuberculosis is thought to be in close contact with ALF prior to encountering host cells (e.g., AMs, neutrophils, alveolar epithelial cells) for an undetermined period of time. ALF contains a series of innate soluble molecules, including homeostatic hydrolytic enzymes (hydrolases) shown to significantly modify the bacterial cell envelope upon contact (Figure 2A). M. tuberculosis exposure to ALF hydrolases happens during the first steps of infection, during its escape of dying cells in the alveolar space, and in cavities during active TB. Upon 15-min contact 
with human ALF, two major M. tuberculosis cell envelope virulent factors, the mannosecapped lipoarabinomannan (ManLAM) and the trehalose dimycolate, are significantly reduced on the bacterial cell surface, among others. These ALF hydrolase-driven alterations define M. tuberculosis-host cell interactions in vitro and in vivo (Figure 2A), and potentially determine the infection and disease outcome [2,3,172-175]. Thus, the in vitro repertoire of potential exposed receptors on the $M$. tuberculosis cell envelope surface being recognized by mycobacteriophages might be modified during the initial stages of infection depending on the host ALF status, potentially directing phage- $M$. tuberculosis interactions in vivo. These human ALF hydrolases are also shown to be expressed at different levels and have altered functionality in elderly individuals, as well as in HIV infected and/or diabetic people compared to healthy individuals. This could potentially alter the cell envelope of $M$. tuberculosis differently, thus making defining phage- $M$. tuberculosis cell surface interactions more challenging depending on the ALF status of a given person at a given time. Moreover, during latent infection $M$. tuberculosis is thought to mainly remain intracellular within the granuloma, where its cell envelope is also thought to experience remodeling due to M. tuberculosis altered metabolic processes within the host cell [176,177].

Most in vitro studies use $M$. tuberculosis grown in solid or liquid medium, where bacteria have not been exposed to lung environment ALF hydrolases and thus, never subjected to the same in vivo bacterial cell surface modifications. This means that there could be well-characterized mycobacteriophages efficient in recognizing and lysing specific M. tuberculosis strains that have been discarded because their testing was performed using in vitro models that do not reflect the impact of the lung environment. As above mentioned, TB comorbidities such as HIV, old age, chronic lung diseases or diabetes, among others, seem to alter ALF status and functionality of different innate immune components in the lung mucosa $[174,178,179]$, possibly driving different modifications on the $M$. tuberculosis cell envelope. As a result, mycobacteriophages that kill very efficiently a particular M. tuberculosis strain in a healthy adult, might not work when the same M. tuberculosis strain infects an elderly or an HIV co-infected individual.

We propose that mycobacteriophage receptors and mycobacteriophage-M.tb interactions should be well characterized and studied for each defined human population (e.g., HIV-infected individuals, elderly, diabetic, etc.) before widely implementing a particular phage therapy strategy. Definitely, the lung environment is a critical factor to take into account that requires further study when designing phage therapies to treat drug-resistant TB. How M. tuberculosis cell envelope changes and adapts during the course of pulmonary infection is also poorly understood, and represents a critical gap in our knowledge for defining new mycobacteriophage receptors in drug-resistant $M$. tuberculosis strains. 


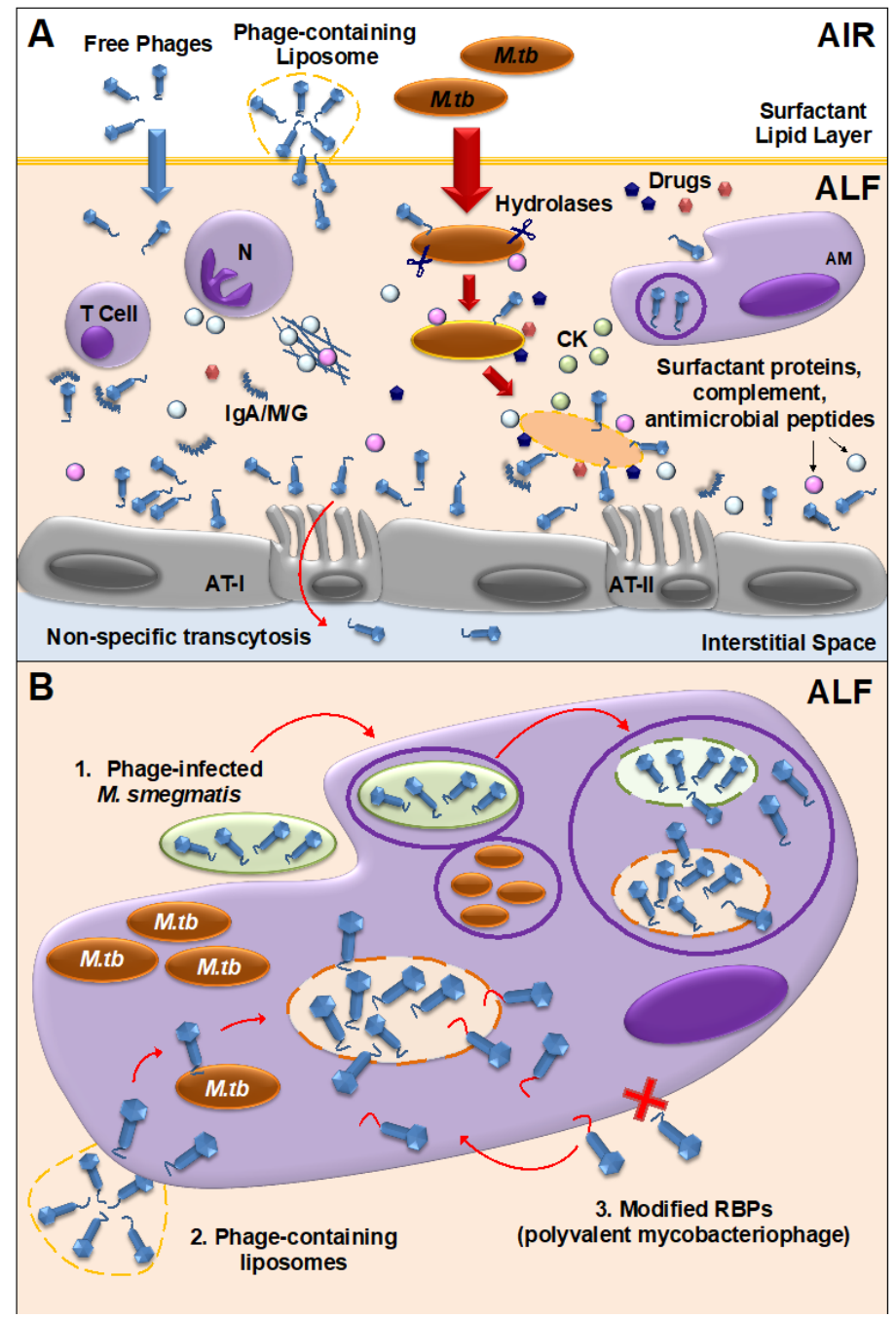

Figure 2. Mycobacteriophage-M. tuberculosis interactions in the human lung alveolar environment. (A) Free and/or encapsulated mycobacteriophages (e.g., in liposomes) reach the lung alveolar space, cross the surfactant lipid layer and are bathed in alveolar lining fluid (ALF), where they can directly or indirectly interact with innate immune cells, generating a local immune response. Some phages will be cleared by phagocytic cells [e.g., alveolar macrophages (AMs)], or by neutralizing antibodies (IgA/M/G). If delivered in sufficient numbers, mycobacteriophages are capable of binding glycan residues in the mucus layer secreted by alveolar epithelial cells type II (AT-II) through Ig-like domains in their capsids, providing an extra non-host antimicrobial protection layer against $M$. tuberculosis infection. Mycobacteriophages can also be translocated to the interstitial space through the epithelium via a non-specific transcytosis mechanism. When $M$. tuberculosis enters the alveolar space, innate soluble molecules in ALF, including hydrolases (represented as scissors), modify the M. tuberculosis cell envelope, driving M. tuberculosis-host cells interactions. These ALF hydrolases-drive alterations will define de novo exposed $M$. tuberculosis surface receptors to be recognized by mycobacteriophages. Here is depicted a combined mycobacteriophage-drug therapy, where drugs and mycobacteriophages work together with an activated mammalian immune response [including neutrophil $(\mathrm{N})$ degranulation and neutrophil extracellular traps [180] secretion, AMs activation, and cytokine and chemokine secretion] to kill $M$. tuberculosis and control the infection. (B) Different strategies can be used to deliver mycobacteriophages inside mammalian cells (e.g., AMs) to access intracellular M. tuberculosis: (1) Mycobacteriophageinfected M. smegmatis bacilli acting as vehicles are phagocytized by AMs being delivered into M. tuberculosis-containing phagosomes. Replicating mycobacteriophages within M. smegmatis lyse the bacterium accessing the phagosome lumen where they recognize, infect and subsequently lyse and kill M. tuberculosis; (2) Liposome-associated mycobacteriophages, which infect mammalian host cells more efficiently than free phages; (3) Generation of polyvalent mycobacteriophages through receptor binding protein (RBP) engineering to recognize mammalian immune cells in addition to receptors on the $M$. tuberculosis cell envelope surface. Note: This figure depicts a general overview of the mycobacteriophage-M. $t b$ interactions in the human lung environment and with the mammalian immune system; and thus, does not fully represent the complexity of the processes described in the text. 


\subsection{Mycobacteriophage-M. tuberculosis Interactions within Mammalian Host Cells}

M. tuberculosis is an intracellular pathogen, known to replicate inside phagocytic and non-phagocytic cells $[172,181]$. In addition, $M$. tuberculosis infection of alveolar cells drives a host immune response that in $95 \%$ of the cases results in the establishment of latent M. tuberculosis infection (LTBI), characterized by the formation of persistent granulomas [176]. Since mycobacteriophages do not seem to have a natural ability to cross mammalian cell membranes (although some level of internalization by endothelial cells has been described for some phages [182]), the fact that $M$. tuberculosis can be found inside macrophages and/or granulomas once the infection is established, represents an added challenge for the development of TB phage therapy strategies [138]. Until recently, it was assumed that mycobacteriophage therapy would only be possible in the case of extracellular pathogens [183], but these past few years, several strategies have been developed to overcome this issue. As an example, bacteria were used as vehicles to carry lytic phages inside murine macrophages to kill intracellular methicillin-resistant S. aureus [184]. In the case of $M$. tuberculosis, mycobacteriophage delivery inside macrophages has been achieved using $M$. smegmatis or liposomes. Besides being fast-growing and non-virulent, M. smegmatis can also serve as host bacterial reservoir for mycobacteriophage proliferation to increase phage titers before reaching the targeted $M$. tuberculosis pathogen $[185,186]$ (Figure 2B). Though M. smegmatis mediated mycobacteriophage delivery has been tested in vitro, due to its pathogenicity in mice models, it may not be a suitable strain to perform phage delivery studies in vivo. However, $M$. smegmatis non-pathogenic $\Delta e s x-3$ mutant strain, which has been tested as a vaccine candidate against $M$. tuberculosis in mice, could be the best carrier for delivering phages into the intracellular compartments [187]. The use of liposomes as a non-bacterial vector proved that liposome-associated TM4 phages infect mammalian cells more efficiently than free phages [188] (Figure 2B). The fact that both systems have proven successful in the delivery of mycobacteriophages inside mammalian cells, opens the possibility for further studies using these systems for the treatment of drugresistant TB either during active TB (bacteria replicating extracellularly and intracellularly) or potentially latent TB (intracellular bacteria at different replication stages).

An alternative strategy could be to engineer mycobacteriophages to recognize and bind host cells, so these can be internalized and have access to intracellular M. tuberculosis (Figure 2B). This has been shown by re-engineering phage M13 to display the penton base of adenoviruses, which mediates viral attachment to integrin receptors and internalization by mammalian cells, without phage replication [189]. Pathogenic bacteria often exploit surface receptors such as mannose receptor on macrophages for phagocytosis wherein ligands such as terminal mannose, fucose or $\mathrm{N}$-acetyl glucosamine are efficiently internalized [190,191]. Mycobacteriophages which are engineered in either capsid or tail proteins to carry ligands such as mannose-6-phosphate can be targeted towards intracellular compartments of macrophages. Such modification in phages is possible with the affinity tagging approaches wherein modified phages carrying affinity tags (e.g., StreptavidinTag II) can be coupled to ligands and used for phage therapy [192].

\subsection{Bacterial Resistance to Mycobacteriophages}

One of the major factors to consider in mycobacteriophage therapy is the potential development of bacterial resistance against phages over time, similar to what happens with drugs. Several mechanisms of bacterial resistance have been described so far [119,193-195], including altering, masking or modifying bacterial receptors to prevent phage adsorption; blocking phage DNA entry through superinfection exclusion (Sie) systems; restriction/modification systems; development of CRISPR (clustered regularly interspaced short palindromic repeats)-Cas systems; abortive infection; interference with the virion particle assembly; etc. but because phages are dynamic and constant evolving entities, they are also capable of developing counter-defense mechanisms to avoid bacterial blockade [196,197], such as mutations of RBPs to recognize alternative receptors in the bacterial surface, expansion of their bacterial host range, and development of anti-CRISPR [198], BREX 
(bacteriophage exclusion defense system) [199] or DISARM (defense island system associated with restriction-modification) [200] mechanisms, among others. This host-phage co-evolution can be influenced by several factors, including phage and bacteria mutation rates and associated fitness cost, population diversity or genetic variability, and it is difficult to predict which bacterial resistance and phage countermeasures will take place at any given moment [201].

In the case of M. tuberculosis, it should be considered that this pathogen is characterized by a low mutation rate of $\sim 2 \times 10^{-10}$ mutations/bp/generation [202] that, in combination with a long replication time of approximately $20 \mathrm{~h}$, highly decreases the probability to develop resistance to mycobacteriophages, which favors the use of phage therapy for the treatment of drug-resistant TB when compared to other pathogens. Still, as these co-evolutionary bacterial-phage dynamics may dictate the therapeutic outcome, several strategies can be applied to shift the balance towards a sustainable phage infection reducing the risk of resistance. Indeed, the use of phage cocktails, preferred over mono-phage preparations, is one of the measures that can be applied to overcome this issue. By using a mixture of genetically diverse phages against several strains of $M$. tuberculosis, one can target synergistically a diverse range of highly conserved receptors on the M. tuberculosis cell envelope surface that are essential for bacterial survival and thus, less prone to mutation [193], minimizing the occurrence of cross-resistance. In addition, $M$. tuberculosis would have to develop resistance to all phages in the mix, which would probably come with a high fitness cost for the bacterium and compromise its survival within the mammalian host [137,203-205]. Still, it is possible that spontaneous resistant clones arise during phage treatment, so it is critical that phage cocktails are constantly tested and updated in order to target newly emerging clones [201]. For M. tuberculosis treatment, it has been suggested that a combination of three to six mycobacteriophages with different resistance countermeasures could be ideal [77]. Indeed, a three-phage cocktail was used in the treatment of disseminated drug-resistant $M$. abscessus subsp. massiliense, a non-tuberculous mycobacterium, in a 15-year-old patient with cystic fibrosis [37]. The patient was not responding to drug treatment and the clinicians, after screening the mycobacteriophage database, used genome engineering to develop a cocktail of three phages (phage Muddy, a lytic derivative phage of ZoeJ, and an expanded host range mutant from phage BP lytic derivative) to efficiently kill the drug-resistant strain. The cocktail was administered intravenously with no adverse effects and showed clinical improvement, reducing infected skin lesions and improved liver function. This study shows promising results and opens the possibility for phage therapy in drug-resistant TB.

Other strategies to reduce the appearance of phage resistance are the use of sequential treatments, in which individual phages with different characteristics are administered one after the other [206], or a combination therapy of phage and drugs [207-209] (Figure 2A). The latter is based on an evolutionary understanding of the fact that a higher number of simultaneous mutations are required for the bacteria to evolve and be able to overcome both phage and antibiotic selective pressures when compared to independent treatments [210]. In addition, if the pathogen develops resistance to the phage, it will probably come with a fitness cost such as decreased virulence or increased sensitivity to antibiotics (if the phage binds to a virulence factor, or if it binds to an antibiotic efflux pump, respectively) [40], which will make the bacteria more vulnerable to the drug. In this case, development of bacterial resistance to phages could be seen as a beneficial trade-off in the elimination of the pathogen. Furthermore, it has been demonstrated that phages can become more effective in killing bacteria in the presence of sub-lethal drug concentrations [208,211], a phenomenon called phage-antibiotic synergy (PAS) (Figure 2A), although some studies have suggested that sub-lethal drug concentrations can actually increase bacterial resistance and thus, high drug concentrations would be more appropriate in combination therapies [212]. Importantly, it has been shown that PAS is not influenced by the drug-resistant status of the bacteria, and that is equally valid to treat MDR pathogens [213]. Other advantages of phage-drug combined therapy are the increased and extended effectiveness, dosage 
reduction, and rapid clearance of the bacterial pathogen when compared to individual treatments. And so, in cases of XDR-, XXDR- or TDR-TB, when the probability of drug treatment success is really low or non-existent, using a phage-drug combined strategy could be an alternative. Finally, for specific settings and cases, the use of personalized treatments could be used to avoid the overuse of generalized phage or drug therapies that would increase the chances of developing bacterial resistance [214].

Overall, more in vitro and in vivo studies exploring the mechanisms of bacterial resistance to phages and mycobacteriophage counter-defenses are needed in order to develop successful phage therapy strategies to treat drug-resistant $\mathrm{TB}$, as very little is known about those mechanisms in M. tuberculosis [161]. Indeed, several M. smegmatis and M. tuberculosis mutants resistant to mycobacteriophages from clusters K, G, or A3 have been isolated, but not fully characterized yet [215].

\subsection{Mycobacteriophage Interactions with the Mammalian Immune System and the Lung Virome}

Recent metagenomic studies have described the ubiquitous presence of viruses as part of the human microbiome, named "virome", including but not restricted to the gut, urinary and vaginal tract, bloodstream, skin and the lungs [216-218]. Among them, phages are typically the most abundant type, found in greater numbers than eukaryotic viruses. The "phageome" has been neglected in most of the previous metagenomic studies, and it is not until recently that its potential impact on commensal microbial communities and its role in host immune responses against bacterial pathogens is starting to be uncovered. As diversification of the phageome is linked to bacterial diversity [219], phages are of special importance in modulating bacterial communities and host-bacterial interactions. Indeed, the lung microbiome is altered in cystic fibrosis patients, where mycobacteriophages and other phages are found infecting cystic fibrosis-associated bacterial pathogens [220], providing further evidence of their possible role in the clearance of pathogen infections within the human body.

The impact of the phageome in the host immune system needs careful consideration when designing treatment strategies. Ideally, a mycobacteriophage selected for therapeutic applications should act at the site of infection but not trigger a generalized immune response. Indeed, phages can interact directly or indirectly with mammalian cells, altering host innate and adaptive immune responses $[108,221]$. As an example of a direct interaction, phages are capable of binding glycan residues present in the mucus layer secreted by the epithelium through Ig-like domains in their capsids [222] (Figure 2A). This observed phenomenon could be of particular interest for the use of mycobacteriophages as prophylactic agents, where phages could be administered in sufficient amounts to bind to the lung mucosal surfaces, providing an extra layer of local innate immune protection against M. tuberculosis infections, with major implications in TB transmission. In fact, proteins with Ig-like domains have been described in several mycobacteriophages [223,224]. Whether these particular mycobacteriophages have sufficient lytic activity against $M$. tuberculosis needs further investigation. Still, this prophylactic strategy could effectively work to stop TB transmission in high burden environments, being used to protect health care professionals or household contacts. Indeed, delivery of D29 mycobacteriophages to the lungs via inhalation in a mouse TB model, as a mean to protect against $M$. tuberculosis infection, showed a decrease in M. tuberculosis burden in lungs at $24 \mathrm{~h}$ and 3 weeks post-infection, indicating a prophylactic effect where phages might be infecting and killing the extracellular bacteria before M. tuberculosis-host cell interactions occur [154].

More recently, it was demonstrated that phages can be translocated through epithelial cells by a non-specific transcytosis mechanism, including intestinal and lung epithelium [182] (Figure 2A), which might explain a systemic presence of phages, especially after oral administration. Systemic mycobacteriophage delivery through intravenous or oral administration may be feasible to treat $\mathrm{TB}$, given that sufficient phages reach the lungs, as high bacterial burden might support phage self-replication to sufficient densities to clear M. tuberculosis from the infection site [225]. However, this amplification might not be 
enough if $M$. tuberculosis bacterial loads are low at the infection site [226], making phage treatment questionable for latent $M$. tuberculosis infection. Another potential issue with oral administration is mycobacteriophage susceptibility to the stomach acidic environment, which could be solved using microencapsulation strategies [227]. Conversely, phages delivered through intranasal or endotracheal routes could probably reach the lungs at higher numbers with limiting systemic effects, being more adequate to treat lung infections such as $\mathrm{TB}$ at their active stage [228,229]. Indeed, aerosol delivery of mycobacteriophage D29 was shown to be effective against $M$. tuberculosis infection and the development of pulmonary TB in the mouse model $[154,155]$. Other studies comparing delivery rate of D29 using different inhalation devices in different animal models concluded that a vibrating mesh nebulizer is the most efficient method for the delivery of high amounts of mycobacteriophages in vivo, whilst the soft mist inhaler might be a better choice for self-administration [230]. And so, nasal delivery of mycobacteriophages for human therapy might be a better strategy through the use of different types of nebulizers and/or inhalers such as dry-powder inhalers (DPIs) or metered-dose inhalers (MDIs) [215]. Nevertheless, mycobacteriophage stability to different environmental tissue conditions is variable, pointing out that same formulation strategies might not be applicable to all mycobacteriophages [227]. Thus, formulation of mycobacteriophage preparations for preservation and storage, effect of environmental tissue stresses on mycobacteriophage stability, release kinetics, or nanoparticle encapsulation and size (which could protect and stabilize phages against adverse environments) are some of the current questions that need answers in order to design optimal individualized mycobacteriophage preparations to treat drug-resistant TB.

It is also important to consider the reduction of phage numbers due to the activation of mammalian host innate and adaptive immune responses when determining the optimal dose/s for a particular phage treatment. Typically, phages are cleared from the human body by phagocytes $[229,231]$ (Figure 2A), even when no phage-specific responses have been developed, although phage lambda mutants escaping innate immune responses were detected [108]. A mammalian host adaptive immune response has also been described, as shown by the production of neutralizing antibodies against phages (Figure 2A), including phages of the human phageome [232], feature that has been traditionally used to test for competence in immunocompromised individuals. In this regard, even though the number of antibodies against naturally-occurring phages does not seem to affect therapy outcome, special attention needs to be given to patients with immune disorders [233], as the mechanisms of phage-immune system interactions, as well as phage immunomodulatory roles are still unclear $[232,234]$. Antibody responses to phages also seem to be related to the administration route and frequency. Particularly, repeated doses of high phage concentrations might be required for successful treatment in order to reach sufficient numbers for bacterial clearance; however, multiple phage doses and/or high phage titers may over activate the immune system, leading to an increased anti-phage antibodies and clearance from the tissue $[119,228]$ and/or adverse effects on the human host. Different strategies have been developed to reduce phage clearance, including the use of appropriate delivery systems such as liposomes to avoid recognition by the immune system [235], or the development of liquid and solid formulations for stabilizing and encapsulating phages [227,236-238].

Conversely, it is unlikely that phages could completely eliminate a bacterial pathogen on their own, as that would imply losing the bacterial host machinery needed for their replication and auto-preservation. While effective phage treatment could significantly reduce the targeted bacterial population, the mammalian immune system is the one that ultimately completely clears pathogen remnants from the tissue. In this process named "Immunophage Synergy", the action of the immune system is necessary and complements the phage antimicrobial activity, as seen in neutrophil-phage cooperation [239] (Figure 2A). Moreover, phages have the potential to indirectly induce anti-inflammatory cytokines through their interaction with host immune cells, helping to reduce inflammation and tissue damage [240]. Conversely, phages also have the ability to stimulate the production 
of IFN- $\gamma$ in a TLR9-dependent manner, linked to exacerbated inflammation in ulcerative colitis (UC) patients [241]; indicating that phage immune interactions might be case-specific and depending on multiple factors such as dose and/or host immune status, among others.

Only a few studies detailing the use of mycobacteriophages to eliminate M. tuberculosis complex are available, with limited data regarding the immunological effects of phage therapeutics [138,242]. Although no documented cases of anaphylaxis have been associated to phage treatment in humans, as opposed to drugs [24,243], it is critical to define the exact immunological responses in order to predict the success of new potential phage therapies to treat drug resistant-TB.

\section{Concluding Remarks and Future Perspectives}

In a "Dry Pipeline" era of drugs, where only a few new compounds are being discovered, the need for alternative strategies to treat emergent MDR, XDR, XXDR and/or TDR M. tuberculosis strains is a priority. The notion of phage therapy against bacterial infections has been around for almost a century due to its numerous advantages. The vast diversity observed in almost 2000 characterized mycobacteriophages opens the possibility of finding highly specific and efficient phages for the elimination of drug-resistant $M$. tuberculosis strains, otherwise associated with untreatable infections. An important concept that has been overlooked in most in vitro mycobacteriophage-bacterial host specificity studies is the impact of the lung environment in shaping the M. tuberculosis cell envelope. It is known that human ALF components interact with and alter the M. tuberculosis cell envelope, defining $M$. tuberculosis-host cell interactions, where the oxidative and inflammatory status and functionality of the ALF determine the nature of these $M$. tuberculosis cell envelope changes [2,174]. This observation could be further exploited to uncover novel mycobacteriophage receptors and to revisit the use of previously discovered mycobacteriophages that were initially dismissed and that could be highly specific when taking into account the impact of the human lung environment. This will require special attention in drug-resistant $M$. tuberculosis strains, as not much is known about their cell envelope composition, the impact of the lung environment, or the potential mycobacteriophage receptors on their surface.

Despite the obvious advantages of using phages as therapeutic agents and promising results from recent studies and clinical trials for several bacterial pathogens [244], there are still several challenges compared to traditional drugs that need to be addressed in order for phage therapy to take off and be acknowledged and widely implemented in modern medicine, being the lack of regulations one of the major obstacles, as well as the need for more robust scientific evidence [245]. Because of that, phage therapy is currently used only on a compassionate care basis. Another critical aspect is the poorly understood specific interactions of mycobacteriophages with the mammalian immune system, posing a question in the scientific community of whether phage preparations are safe for human use. Phages are known to interact with host cells and generate and modulate directly or indirectly host innate and adaptive immunity, but their exact immunomodulatory properties and specific mechanisms are still largely unknown. Ideally, a mycobacteriophage used in phage therapy should reach the lungs in sufficient numbers and be able to work synergistically with the host innate immune system (and drugs, in a combined phagedrug therapy) to clear the infection, but without causing a dysregulated systemic immune reaction or adverse effects. Special attention needs to be given to the excessive generation of phage-neutralizing antibodies, which can represent a hurdle in phage therapy applications by rapidly clearing the phages before eliminating $M$. tuberculosis [40]. Thus, a perfect balance in the activation of the host immune system needs to be reached for a successful outcome, which will likely depend on the administration route, the dose, and the host's immune status, among other factors. In this regard, a concept to explore would be the use of phages to generate a low-level protective immune response to prevent $M$. tuberculosis infections. TB comorbidities such as aging, HIV co-infection, and chronic disease such as diabetes alter the host's immune response [174] and consequently, a particular phage 
treatment that would work for a healthy individual might not work in these cases, stressing the need for more personalized treatments.

The fact that phages are evolving entities is considered an advantage for phage therapy, although it can also constitute a limitation. On one hand, it can help phages overcome the development of bacterial resistance and also reduce the treatment dose thanks to their ability to replicate in the presence of their host, but at the same time, phages can acquire harmful properties by horizontal gene transfer through the interaction with the human microbiota. Thus, there are also important evolutionary consequences related to phage therapy that need to be addressed before it can be implemented, such as the effect of phages in complex bacterial populations or phage-bacterial host co-evolution. To start addressing this, methods are being developed for a more controlled phage therapy by conjugating phages to gold nanorods, whose excitation by near-infrared light causes localized heating that destroys phage-infected bacteria, without harming nearby mammalian host cells [246].

Currently, due to mycobacteriophage therapy clinical practicality, this may be only used on the most difficult or virtually incurable cases of drug-resistant $\mathrm{TB}$, where drug therapy does not work or is insufficient. Phage therapy alone may never completely replace the use of traditional drugs, but combined mycobacteriophage-drug therapies working together and enhancing the stimulation of the host immune response might prove to be the most efficient in the long run for several reasons. First, it makes sense from an evolutionary point of view, as it can prevent the potential appearance of bacterial resistance to mycobacteriophages, as previously discussed. Second, it has been suggested that both phages and drugs in combination are more effective in controlling pathogenic bacteria than either alone. This synergistic effect has been observed in numerous studies, independent of the drug-resistance status of the pathogen [208], which, in the case of $\mathrm{TB}$, would allow shortening of treatment duration and/or reduction in drug dosage. Consequently, this could prevent further development of drug-resistance. As a direct benefit, the standardized use of combined therapies in MDR patients worldwide could reduce the conversion, and thus, cases, of XDR and XXDR-TB, as these are generated from MDR cases failing their treatment. To what extent mycobacteriophages in combination with drugs can be used as routine therapy is difficult to assess, especially in TB endemic areas that are linked to low-income regions. Using mycobacteriophages as prophylactic instead of therapeutic agents might be a better strategy in these regions, where therapy-associated costs and patient non-adherence to treatment represents a huge problem and potentiates the emergence of drug-resistant $M$. tuberculosis strains, further increasing the treatment costs. By eliminating $M$. tuberculosis before the potential establishment of the infection, transmission is drastically reduced, decreasing treatment costs. In this regard, regular mycobacteriophage administration in high-risk individuals (e.g., household contacts of TB patients) could be exploited as a prophylactic measure to prevent onset of TB disease instead of preventive TB therapy, which uses drugs. This strategy would generate nonmammalian host-derived immune protection in the lung mucosal surfaces by using highly specific and effective phages that could quickly kill extracellular M. tuberculosis before the establishment of the infection, or work together with the host innate response in this matter. Still, the impact of the constant presence of mycobacteriophages in the lung microbiome and the host immunity generated by them would need to be well-established prior to even considering their therapeutic use.

These potential strategies might be used in the near future, where exploiting the use of mycobacteriophages to aid resolving drug-resistant $\mathrm{TB}$ cases could be a valid option when drugs fail to do so. However, before this, selective, effective, safe, and standardized phage preparations will need to be established [247], that in combination with drugs and the host immune response, might help to treat otherwise untreatable TB. In this scenario, the development of bioinformatics pipelines to predict phage and $M$. tuberculosis binding sites, phage efficacy, etc., that account for the host tissue environment, will be required to define phages with highly specific recognition and killing efficacy against drug-resistant M. tuberculosis strains. 
Author Contributions: A.A.-G., R.S., J.C., and J.B.T. made substantial contributions to the conception, writing, and editing of this review. All authors have read and agreed to the published version of the manuscript.

Funding: This work has been partially supported by the Robert J. Kleberg and Helen C. Kleberg Foundation to J.B.T., and by the National Institutes of Health/National Institute of Allergy and Infectious Diseases (NIH/NIAID) grant numbers R01 AI146340 to J.C. and J.B.T, R01 AI-137344 and R01 AI-139297 to J.C., and R01 AI-026170 and R21 AI-156853 to R.S.

Institutional Review Board Statement: Not applicable.

Informed Consent Statement: Not applicable.

Data Availability Statement: No new data were created or analyzed in this study. Data sharing is not applicable to this article.

Acknowledgments: We thank Texas Biomedical Research Institute personnel for their support and efforts to keep the institute open during the COVID-19 pandemic.

Conflicts of Interest: The authors declare no conflict of interest. The funders had no role in the writing of the manuscript.

\section{References}

1. WHO. Global Tuberculosis Report 2020; WHO: Geneva, Switzerland, 2020.

2. Arcos, J.; Sasindran, S.J.; Fujiwara, N.; Turner, J.; Schlesinger, L.S.; Torrelles, J.B. Human lung hydrolases delineate Mycobacterium tuberculosis-macrophage interactions and the capacity to control infection. J. Immunol. 2011, 187, 372-381. [CrossRef] [PubMed]

3. Torrelles, J.B.; Schlesinger, L.S. Integrating Lung Physiology, Immunology, and Tuberculosis. Trends Microbiol. 2017, 25, 688-697. [CrossRef] [PubMed]

4. Zaman, K. Tuberculosis: A global health problem. J. Health Popul. Nutr. 2010, 28, 111-113. [CrossRef] [PubMed]

5. Ellner, J.J. The emergence of extensively drug-resistant tuberculosis: A global health crisis requiring new interventions: Part I: The origins and nature of the problem. Clin. Transl. Sci. 2008, 1, 249-254. [CrossRef]

6. Loewenberg, S. India reports cases of totally drug-resistant tuberculosis. Lancet 2012, 379, 205. [CrossRef]

7. Klopper, M.; Warren, R.M.; Hayes, C.; Gey van Pittius, N.C.; Streicher, E.M.; Muller, B.; Sirgel, F.A.; Chabula-Nximeni, M.; Hoosain, E.; Coetzee, G.; et al. Emergence and spread of extensively and totally drug-resistant tuberculosis, South Africa. Emerg. Infect. Dis. 2013, 19, 449-455. [CrossRef]

8. LoBue, P. Extensively drug-resistant tuberculosis. Curr. Opin Infect. Dis. 2009, 22, 167-173. [CrossRef]

9. Velayati, A.A.; Masjedi, M.R.; Farnia, P.; Tabarsi, P.; Ghanavi, J.; ZiaZarifi, A.H.; Hoffner, S.E. Emergence of new forms of totally drug-resistant tuberculosis bacilli: Super extensively drug-resistant tuberculosis or totally drug-resistant strains in iran. Chest 2009, 136, 420-425. [CrossRef]

10. Migliori, G.B.; Centis, R.; D’Ambrosio, L.; Spanevello, A.; Borroni, E.; Cirillo, D.M.; Sotgiu, G. Totally drug-resistant and extremely drug-resistant tuberculosis: The same disease? Clin. Infect. Dis 2012, 54, 1379-1380. [CrossRef]

11. WHO. Drug-Resistant TB: Totally Drug-Resistant TB FAQ. Available online: https:/ /www.who.int/tb/areas-of-work/drugresistant-tb/totally-drug-resistant-tb-faq/en/ (accessed on 3 March 2020).

12. Velayati, A.A.; Farnia, P.; Masjedi, M.R. The totally drug resistant tuberculosis (TDR-TB). Int. J. Clin. Exp. Med. 2013, 6, 307-309. [PubMed]

13. Burki, T.K. The uphill battle to find new TB treatments. Lancet Respir Med. 2017. [CrossRef]

14. Lange, C.; Chesov, D.; Heyckendorf, J.; Leung, C.C.; Udwadia, Z.; Dheda, K. Drug-resistant tuberculosis: An update on disease burden, diagnosis and treatment. Respirology 2018, 23, 656-673. [CrossRef]

15. Velayati, A.A.; Farnia, P.; Masjedi, M.R.; Ibrahim, T.A.; Tabarsi, P.; Haroun, R.Z.; Kuan, H.O.; Ghanavi, J.; Farnia, P.; Varahram, M. Totally drug-resistant tuberculosis strains: Evidence of adaptation at the cellular level. Eur. Respir. J. 2009, 34, $1202-1203$. [CrossRef] [PubMed]

16. Wilkinson, L. Felix d'Herelle and the origins of molecular biology. Med. Hist. 2001, 45, 294-295. [CrossRef]

17. Chanishvili, N. Phage Therapy-History from Twort and d'Herelle Through Soviet Experience to Current Approaches. Adv. Virus Res. 2012, 83, 3-40. [CrossRef] [PubMed]

18. Sulakvelidze, A.; Alavidze, Z.; Morris, J.G., Jr. Bacteriophage therapy. Antimicrob. Agents Chemother. 2001, 45, 649-659. [CrossRef]

19. Dublanchet, A.; Bourne, S. The epic of phage therapy. Can. J. Infect. Dis. Med. Microbiol. 2007, 18, 15-18. [CrossRef]

20. Kokin, G.A. Phage therapy and phage prophylaxis of gas gangrene. In Experience of the Soviet Military Medicine during the Great Patriotic War 1941-1945; Medgiz: Moscow, Russia, 1946; Volume 3.

21. Lin, D.M.; Koskella, B.; Lin, H.C. Phage therapy: An alternative to antibiotics in the age of multi-drug resistance. World J. Gastrointest. Pharmacol. Ther. 2017, 8, 162-173. [CrossRef] 
22. Merabishvili, M.; Pirnay, J.P.; Verbeken, G.; Chanishvili, N.; Tediashvili, M.; Lashkhi, N.; Glonti, T.; Krylov, V.; Mast, J.; Van Parys, L.; et al. Quality-Controlled Small-Scale Production of a Well-Defined Bacteriophage Cocktail for Use in Human Clinical Trials. PLoS ONE 2009, 4, e4944. [CrossRef]

23. Markoishvili, K.; Tsitlanadze, G.; Katsarava, R.; Morris, J.G.; Sulakvelidze, A. A novel sustained-release matrix based on biodegradable poly(ester amide)s and impregnated with bacteriophages and an antibiotic shows promise in management of infected venous stasis ulcers and other poorly healing wounds. Int. J. Dermatol. 2002, 41, 453-458. [CrossRef]

24. McCallin, S.; Sarker, S.A.; Sultana, S.; Oechslin, F.; Brussow, H. Metagenome analysis of Russian and Georgian Pyophage cocktails and a placebo-controlled safety trial of single phage versus phage cocktail in healthy Staphylococcus aureus carriers. Environ. Microbiol. 2018, 20, 3278-3293. [CrossRef] [PubMed]

25. Villarroel, J.; Larsen, M.V.; Kilstrup, M.; Nielsen, M. Metagenomic Analysis of Therapeutic PYO Phage Cocktails from 1997 to 2014. Viruses 2017, 9, 328. [CrossRef] [PubMed]

26. Kutateladze, M. Experience of the Eliava Institute in bacteriophage therapy. Virol. Sin. 2015, 30, 80-81. [CrossRef]

27. Gorski, A.; Miedzybrodzki, R.; Borysowski, J.; Weber-Dabrowska, B.; Lobocka, M.; Fortuna, W.; Letkiewicz, S.; Zimecki, M.; Filby, G. Bacteriophage therapy for the treatment of infections. Curr. Opin Investig. Drugs 2009, 10, 766-774.

28. Furfaro, L.L.; Payne, M.S.; Chang, B.J. Bacteriophage Therapy: Clinical Trials and Regulatory Hurdles. Front. Cell Infect. Microbiol. 2018, 8, 376. [CrossRef] [PubMed]

29. Wienhold, S.M.; Lienau, J.; Witzenrath, M. Towards Inhaled Phage Therapy in Western Europe. Viruses 2019, 11, 295. [CrossRef]

30. Hoopes, J.T.; Stark, C.J.; Kim, H.A.; Sussman, D.J.; Donovan, D.M.; Nelson, D.C. Use of a bacteriophage lysin, PlyC, as an enzyme disinfectant against Streptococcus equi. Appl. Environ. Microbiol. 2009, 75, 1388-1394. [CrossRef] [PubMed]

31. Brovko, L.Y.; Anany, H.; Griffiths, M.W. Bacteriophages for detection and control of bacterial pathogens in food and foodprocessing environment. Adv. Food Nutr. Res. 2012, 67, 241-288. [CrossRef] [PubMed]

32. Alvarez, B.; Biosca, E.G. Bacteriophage-Based Bacterial Wilt Biocontrol for an Environmentally Sustainable Agriculture. Front. Plant. Sci. 2017, 8, 1218. [CrossRef] [PubMed]

33. Tseng, C.C.; Chang, D.C.; Chang, K.C. Development of a Biocontrol Method Applying Bacteriophage-Containing Aerosol against Mycobacterium tuberculosis Using the Bacteriophage BTCU-1 and M. smegmatis as Models. Microorganisms 2019 , 7, 237. [CrossRef] [PubMed]

34. Stone, E.; Campbell, K.; Grant, I.; McAuliffe, O. Understanding and Exploiting Phage-Host Interactions. Viruses 2019, 11, 567. [CrossRef]

35. Lohrasbi, V.; Talebi, M.; Bialvaei, A.Z.; Fattorini, L.; Drancourt, M.; Heidary, M.; Darban-Sarokhalil, D. Trends in the discovery of new drugs for Mycobacterium tuberculosis therapy with a glance at resistance. Tuberculosis 2018, 109, 17-27. [CrossRef] [PubMed]

36. LaVergne, S.; Hamilton, T.; Biswas, B.; Kumaraswamy, M.; Schooley, R.T.; Wooten, D. Phage Therapy for a Multidrug-Resistant Acinetobacter baumannii Craniectomy Site Infection. Open Forum. Infect. Dis. 2018, 5, ofy064. [CrossRef] [PubMed]

37. Dedrick, R.M.; Guerrero-Bustamante, C.A.; Garlena, R.A.; Russell, D.A.; Ford, K.; Harris, K.; Gilmour, K.C.; Soothill, J.; Jacobs-Sera, D.; Schooley, R.T.; et al. Engineered bacteriophages for treatment of a patient with a disseminated drug-resistant Mycobacterium abscessus. Nat. Med. 2019, 25, 730-733. [CrossRef]

38. Jeon, J.; Park, J.H.; Yong, D. Efficacy of bacteriophage treatment against carbapenem-resistant Acinetobacter baumannii in Galleria mellonella larvae and a mouse model of acute pneumonia. BMC Microbiol. 2019, 19, 70. [CrossRef] [PubMed]

39. Tkhilaishvili, T.; Winkler, T.; Muller, M.; Perka, C.; Trampuz, A. Bacteriophages as adjuvant to antibiotics for the treatment of periprosthetic joint infection caused by multidrug-resistant Pseudomonas aeruginosa. Antimicrob. Agents Chemother. 2019, 64, 1128. [CrossRef] [PubMed]

40. Kortright, K.E.; Chan, B.K.; Koff, J.L.; Turner, P.E. Phage Therapy: A Renewed Approach to Combat Antibiotic-Resistant Bacteria. Cell Host Microbe 2019, 25, 219-232. [CrossRef] [PubMed]

41. Gardner, G.M.; Weiser, R.S. A bacteriophage for Mycobacterium smegmatis. Proc. Soc. Exp. Biol Med. 1947, 66, 205. [CrossRef] [PubMed]

42. Sula, L.; Sulova, J.; Stolcpartova, M. Phage typing of South Indian M. tuberculosis strains by "surface" and "overlay" method. Czech. Med. 1981, 4, 215-223.

43. Goode, D. Bacteriophage typing of strains of Mycobacterium tuberculosis from Nepal. Tubercle 1983, 64, 15-21. [CrossRef]

44. Raj, C.V.; Ramakrishnan, T. Transduction in Mycobacterium smegmatis. Nature 1970, 228, 280-281. [CrossRef]

45. Imaeda, T. Ultrastructure of L-phase variants isolated from a culture of Mycobacterium phlei. J. Med. Microbiol. 1975, 8, 389-395. [CrossRef] [PubMed]

46. Fay, D.; Bowman, B.U. Structure of native and chloroform-methanol-treated mycobacteriophage R1. J. Virol. 1978, 27, 432-435. [CrossRef] [PubMed]

47. Jones, W.; White, A. Lysogeny in mycobacteria. I. Conversion of colony morphology, nitrate reductase activity, and tween 80 hydrolysis of Mycobacterium sp. ATCC 607 associated with lysogeny. Can. J. Microbiol. 1968, 14, 551-555. [CrossRef]

48. Schafer, R.; Huber, U.; Franklin, R.M. Chemical and physical properties of mycobacteriophage D29. Eur. J. Biochem. 1977, 73, 239-246. [CrossRef]

49. Bardarov, S.; Kriakov, J.; Carriere, C.; Yu, S.; Vaamonde, C.; McAdam, R.A.; Bloom, B.R.; Hatfull, G.F.; Jacobs, W.R., Jr. Conditionally replicating mycobacteriophages: A system for transposon delivery to Mycobacterium tuberculosis. Proc. Natl. Acad. Sci. USA 1997, 94, 10961-10966. [CrossRef] [PubMed] 
50. Hatfull, G.F.; Sarkis, G.J. DNA sequence, structure and gene expression of mycobacteriophage L5: A phage system for mycobacterial genetics. Mol. Microbiol. 1993, 7, 395-405. [CrossRef] [PubMed]

51. Jacobs, W.R., Jr.; Tuckman, M.; Bloom, B.R. Introduction of foreign DNA into mycobacteria using a shuttle phasmid. Nature 1987, 327, 532-535. [CrossRef] [PubMed]

52. Jacobs, W.R., Jr. Gene Transfer in Mycobacterium tuberculosis: Shuttle Phasmids to Enlightenment. Microbiol. Spectr. 2014, 2. [CrossRef] [PubMed]

53. Lee, S.; Kriakov, J.; Vilcheze, C.; Dai, Z.; Hatfull, G.F.; Jacobs, W.R., Jr. Bxz1, a new generalized transducing phage for mycobacteria. FEMS Microbiol. Lett. 2004, 241, 271-276. [CrossRef] [PubMed]

54. van Kessel, J.C.; Hatfull, G.F. Efficient point mutagenesis in mycobacteria using single-stranded DNA recombineering: Characterization of antimycobacterial drug targets. Mol. Microbiol. 2008, 67, 1094-1107. [CrossRef] [PubMed]

55. Hatfull, G.F. Molecular Genetics of Mycobacteriophages. Microbiol. Spectr. 2014, 2, 1-36. [CrossRef] [PubMed]

56. Arora, G.; Chaudhary, D.; Kidwai, S.; Sharma, D.; Singh, R. CitE Enzymes Are Essential for Mycobacterium tuberculosis to Establish Infection in Macrophages and Guinea Pigs. Front. Cell Infect. Microbiol. 2018, 8, 385. [CrossRef] [PubMed]

57. Marinelli, L.J.; Piuri, M.; Hatfull, G.F. Genetic Manipulation of Lytic Bacteriophages with BRED: Bacteriophage Recombineering of Electroporated DNA. Methods Mol. Biol. 2019, 1898, 69-80. [CrossRef]

58. Petrova, Z.O.; Broussard, G.W.; Hatfull, G.F. Mycobacteriophage-repressor-mediated immunity as a selectable genetic marker: Adephagia and BPs repressor selection. Microbiology 2015, 161, 1539-1551. [CrossRef]

59. McNerney, R.; Kiepiela, P.; Bishop, K.S.; Nye, P.M.; Stoker, N.G. Rapid screening of Mycobacterium tuberculosis for susceptibility to rifampicin and streptomycin. Int. J. Tuberc Lung Dis. 2000, 4, 69-75.

60. Swift, B.M.; Convery, T.W.; Rees, C.E. Evidence of Mycobacterium tuberculosis complex bacteraemia in intradermal skin test positive cattle detected using phage-RPA. Virulence 2016, 7, 779-788. [CrossRef] [PubMed]

61. Jacobs, W.R., Jr.; Barletta, R.G.; Udani, R.; Chan, J.; Kalkut, G.; Sosne, G.; Kieser, T.; Sarkis, G.J.; Hatfull, G.F.; Bloom, B.R. Rapid assessment of drug susceptibilities of Mycobacterium tuberculosis by means of luciferase reporter phages. Science 1993, 260, 819-822. [CrossRef]

62. Carriere, C.; Riska, P.F.; Zimhony, O.; Kriakov, J.; Bardarov, S.; Burns, J.; Chan, J.; Jacobs, W.R., Jr. Conditionally replicating luciferase reporter phages: Improved sensitivity for rapid detection and assessment of drug susceptibility of Mycobacterium tuberculosis. J. Clin. Microbiol. 1997, 35, 3232-3239. [CrossRef] [PubMed]

63. Riska, P.F.; Jacobs, W.R., Jr.; Bloom, B.R.; McKitrick, J.; Chan, J. Specific identification of Mycobacterium tuberculosis with the luciferase reporter mycobacteriophage: Use of p-nitro-alpha-acetylamino-beta-hydroxy propiophenone. J. Clin. Microbiol. 1997, 35, 3225-3231. [CrossRef] [PubMed]

64. Jain, P.; Garing, S.; Verma, D.; Saranathan, R.; Clute-Reinig, N.; Gadwa, J.; Peterson, C.; Hermansky, G.; Astashkina Fernandez, A.; Asare, E.; et al. Nanoluciferase Reporter Mycobacteriophage for Sensitive and Rapid Detection of Mycobacterium tuberculosis Drug Susceptibility. J. Bacteriol. 2020, 202. [CrossRef]

65. Piuri, M.; Jacobs, W.R., Jr.; Hatfull, G.F. Fluoromycobacteriophages for rapid, specific, and sensitive antibiotic susceptibility testing of Mycobacterium tuberculosis. PLoS ONE 2009, 4, e4870. [CrossRef] [PubMed]

66. Crowley, G.C.; O’Mahony, J.; Coffey, A.; Sayers, R.; Cotter, P. A rapid viability and drug-susceptibility assay utilizing mycobacteriophage as an indicator of drug susceptibilities of Anti-TB drugs against Mycobacterium smegmatis mc(2) 155. Int. J. Mycobacteriol. 2019, 8, 124-131. [CrossRef] [PubMed]

67. Rondon, L.; Urdaniz, E.; Latini, C.; Payaslian, F.; Matteo, M.; Sosa, E.J.; Do Porto, D.F.; Turjanski, A.G.; Nemirovsky, S.; Hatfull, G.F.; et al. Fluoromycobacteriophages Can Detect Viable Mycobacterium tuberculosis and Determine Phenotypic Rifampicin Resistance in 3-5 Days From Sputum Collection. Front. Microbiol. 2018, 9, 1471. [CrossRef] [PubMed]

68. Piuri, M.; Hatfull, G.F. Fluoromycobacteriophages for Drug Susceptibility Testing (DST) of Mycobacteria. Methods Mol. Biol. 2019, 1898, 27-36. [CrossRef] [PubMed]

69. O'Donnell, M.R.; Larsen, M.H.; Brown, T.S.; Jain, P.; Munsamy, V.; Wolf, A.; Uccellini, L.; Karim, F.; de Oliveira, T.; Mathema, B.; et al. Early Detection of Emergent Extensively Drug-Resistant Tuberculosis by Flow Cytometry-Based Phenotyping and Whole-Genome Sequencing. Antimicrob. Agents Chemother. 2019, 63. [CrossRef]

70. Jain, P.; Weinrick, B.C.; Kalivoda, E.J.; Yang, H.; Munsamy, V.; Vilcheze, C.; Weisbrod, T.R.; Larsen, M.H.; O’Donnell, M.R.; Pym, A.; et al. Dual-Reporter Mycobacteriophages (Phi2DRMs) Reveal Preexisting Mycobacterium tuberculosis Persistent Cells in Human Sputum. MBio 2016, 7, e01023-16. [CrossRef] [PubMed]

71. Hatfull, G.F.; Russell, D.; Jacobs-Sera, D.; Pope, W.H.; Sivanathan, V. The Actinobacteriophage Database. Available online: https:/ / phagesdb.org/hosts/genera/1/ (accessed on 3 March 2020).

72. Russell, D.A.; Hatfull, G.F. PhagesDB: The actinobacteriophage database. Bioinformatics 2017, 33, 784-786. [CrossRef] [PubMed]

73. Bajpai, U.; Mehta, A.K.; Eniyan, K.; Sinha, A.; Ray, A.; Virdi, S.; Ahmad, S.; Shah, A.; Arora, D.; Marwaha, D.; et al. Isolation and characterization of bacteriophages from India, with lytic activity against Mycobacterium tuberculosis. Can. J. Microbiol. 2018, 64, 483-491. [CrossRef]

74. Satish, R.; Desouza, A. Study of characteristics of mycobacteriophage-A novel tool to treat Mycobacterium spp. Int. J. Mycobacteriol. 2019, 8, 170-174. [CrossRef] [PubMed]

75. Ackermann, H.W. Tailed bacteriophages: The order caudovirales. Adv. Virus Res. 1998, 51, 135-201. [CrossRef] [PubMed] 
76. Dion, M.B.; Oechslin, F.; Moineau, S. Phage diversity, genomics and phylogeny. Nat. Rev. Microbiol. 2020, 18, 125-138. [CrossRef] [PubMed]

77. Hatfull, G.F. Mycobacteriophages. Microbiol. Spectr. 2018, 6. [CrossRef] [PubMed]

78. Pope, W.H.; Bowman, C.A.; Russell, D.A.; Jacobs-Sera, D.; Asai, D.J.; Cresawn, S.G.; Jacobs, W.R.; Hendrix, R.W.; Lawrence, J.G.; Hatfull, G.F.; et al. Whole genome comparison of a large collection of mycobacteriophages reveals a continuum of phage genetic diversity. Elife 2015, 4, e06416. [CrossRef] [PubMed]

79. Pedulla, M.L.; Ford, M.E.; Houtz, J.M.; Karthikeyan, T.; Wadsworth, C.; Lewis, J.A.; Jacobs-Sera, D.; Falbo, J.; Gross, J.; Pannunzio, N.R.; et al. Origins of highly mosaic mycobacteriophage genomes. Cell 2003, 113, 171-182. [CrossRef]

80. Hatfull, G.F.; Pedulla, M.L.; Jacobs-Sera, D.; Cichon, P.M.; Foley, A.; Ford, M.E.; Gonda, R.M.; Houtz, J.M.; Hryckowian, A.J.; Kelchner, V.A.; et al. Exploring the mycobacteriophage metaproteome: Phage genomics as an educational platform. PLoS Genet. 2006, 2, e92. [CrossRef]

81. Hatfull, G.F. Mycobacteriophages: Genes and genomes. Annu. Rev. Microbiol. 2010, 64, 331-356. [CrossRef] [PubMed]

82. Dedrick, R.M.; Mavrich, T.N.; Ng, W.L.; Cervantes Reyes, J.C.; Olm, M.R.; Rush, R.E.; Jacobs-Sera, D.; Russell, D.A.; Hatfull, G.F. Function, expression, specificity, diversity and incompatibility of actinobacteriophage parABS systems. Mol. Microbiol. 2016, 101, 625-644. [CrossRef]

83. Morgado, S.M.; Vicente, A.C.P. Beyond the Limits: tRNA Array Units in Mycobacterium Genomes. Front. Microbiol. 2018, 9, 1042. [CrossRef] [PubMed]

84. Kelley, D.S.; Lennon, C.W.; Sea, P.; Belfort, M.; Novikova, O. Mycobacteriophages as Incubators for Intein Dissemination and Evolution. MBio 2016, 7, e01537-16. [CrossRef]

85. Hatfull, G.F.; Jacobs-Sera, D.; Lawrence, J.G.; Pope, W.H.; Russell, D.A.; Ko, C.C.; Weber, R.J.; Patel, M.C.; Germane, K.L.; Edgar, R.H.; et al. Comparative genomic analysis of 60 Mycobacteriophage genomes: Genome clustering, gene acquisition, and gene size. J. Mol. Biol. 2010, 397, 119-143. [CrossRef] [PubMed]

86. Ko, C.C.; Hatfull, G.F. Mycobacteriophage Fruitloop gp52 inactivates Wag31 (DivIVA) to prevent heterotypic superinfection. Mol. Microbiol. 2018, 108, 443-460. [CrossRef]

87. Ko, C.C.; Hatfull, G.F. Identification of mycobacteriophage toxic genes reveals new features of mycobacterial physiology and morphology. Sci. Rep. 2020, 10, 14670. [CrossRef] [PubMed]

88. Dedrick, R.M.; Jacobs-Sera, D.; Bustamante, C.A.; Garlena, R.A.; Mavrich, T.N.; Pope, W.H.; Reyes, J.C.; Russell, D.A.; Adair, T.; Alvey, R.; et al. Prophage-mediated defence against viral attack and viral counter-defence. Nat. Microbiol. 2017, $2,16251$. [CrossRef] [PubMed]

89. Gentile, G.M.; Wetzel, K.S.; Dedrick, R.M.; Montgomery, M.T.; Garlena, R.A.; Jacobs-Sera, D.; Hatfull, G.F. More Evidence of Collusion: A New Prophage-Mediated Viral Defense System Encoded by Mycobacteriophage Sbash. MBio 2019, 10, e00196-19. [CrossRef] [PubMed]

90. Mavrich, T.N.; Hatfull, G.F. Evolution of Superinfection Immunity in Cluster A Mycobacteriophages. MBio 2019, 10, e00971-19. [CrossRef] [PubMed]

91. Lima-Junior, J.D.; Viana-Niero, C.; Conde Oliveira, D.V.; Machado, G.E.; Rabello, M.C.; Martins-Junior, J.; Martins, L.F.; Digiampietri, L.A.; da Silva, A.M.; Setubal, J.C.; et al. Characterization of mycobacteria and mycobacteriophages isolated from compost at the Sao Paulo Zoo Park Foundation in Brazil and creation of the new mycobacteriophage Cluster U. BMC Microbiol. 2016, 16, 111. [CrossRef]

92. Suarez, C.A.; Franceschelli, J.J.; Morbidoni, H.R. Mycobacteriophage CRB2 defines a new subcluster in mycobacteriophage classification. PLoS ONE 2019, 14, e0212365. [CrossRef] [PubMed]

93. Fast, K.M.; Keener, T.; Ali, R.; Butcher, B.M.; Millwood, J.D.; Odom, T.; Schellhammer, P.K.; Ufomadu, E.; Sandel, M.W. Genome Sequence of a Newly Isolated F2 Subcluster Mycobacteriophage from the Black Belt Geological Region of Western Alabama. Genome Announc. 2018, 6. [CrossRef] [PubMed]

94. Saadhali, S.A.; Hassan, S.; Hanna, L.E.; Ranganathan, U.D.; Kumar, V. Homology modeling, substrate docking, and molecular simulation studies of mycobacteriophage Che12 lysin A. J. Mol. Model. 2016, 22, 180. [CrossRef]

95. Pimentel, M. Genetics of Phage Lysis. Microbiol. Spectr. 2014, 2. [CrossRef] [PubMed]

96. Joshi, H.; Nair, G.; Gangakhedkar, R.; Jain, V. Understanding the role of the lysozyme-like domain of D29 mycobacteriophageencoded endolysin in host cell lysis and phage propagation. Microbiology 2019, 165, 1013-1023. [CrossRef] [PubMed]

97. Catalao, M.J.; Pimentel, M. Mycobacteriophage Lysis Enzymes: Targeting the Mycobacterial Cell Envelope. Viruses 2018, 10, 428. [CrossRef] [PubMed]

98. Joshi, H.; Seniya, S.P.; Suryanarayanan, V.; Patidar, N.D.; Singh, S.K.; Jain, V. Dissecting the structure-function relationship in lysozyme domain of mycobacteriophage D29-encoded peptidoglycan hydrolase. FEBS Lett. 2017, 591, 3276-3287. [CrossRef] [PubMed]

99. Bavda, V.R.; Jain, V. Deciphering the Role of Holin in Mycobacteriophage D29 Physiology. Front. Microbiol. 2020, 11, 883. [CrossRef] [PubMed]

100. Catalao, M.J.; Gil, F.; Moniz-Pereira, J.; Pimentel, M. The mycobacteriophage Ms6 encodes a chaperone-like protein involved in the endolysin delivery to the peptidoglycan. Mol. Microbiol. 2010, 77, 672-686. [CrossRef] [PubMed]

101. Dulberger, C.L.; Rubin, E.J.; Boutte, C.C. The mycobacterial cell envelope-A moving target. Nat. Rev. Microbiol. 2020, 18, 47-59. [CrossRef] [PubMed] 
102. Gigante, A.M.; Hampton, C.M.; Dillard, R.S.; Gil, F.; Catalao, M.J.; Moniz-Pereira, J.; Wright, E.R.; Pimentel, M. The Ms6 MycolylArabinogalactan Esterase LysB is Essential for an Efficient Mycobacteriophage-Induced Lysis. Viruses 2017, 9, 343. [CrossRef]

103. Payne, K.; Sun, Q.; Sacchettini, J.; Hatfull, G.F. Mycobacteriophage Lysin B is a novel mycolylarabinogalactan esterase. Mol. Microbiol. 2009, 73, 367-381. [CrossRef]

104. Gil, F.; Grzegorzewicz, A.E.; Catalao, M.J.; Vital, J.; McNeil, M.R.; Pimentel, M. Mycobacteriophage Ms6 LysB specifically targets the outer membrane of Mycobacterium smegmatis. Microbiology 2010, 156, 1497-1504. [CrossRef]

105. Garcia-Vilanova, A.; Chan, J.; Torrelles, J.B. Underestimated Manipulative Roles of Mycobacterium tuberculosis Cell Envelope Glycolipids During Infection. Front. Immunol. 2019, 10, 2909. [CrossRef] [PubMed]

106. Fraga, A.G.; Trigo, G.; Murthy, R.K.; Akhtar, S.; Hebbur, M.; Pacheco, A.R.; Dominguez, J.; Silva-Gomes, R.; Goncalves, C.M.; Oliveira, H.; et al. Antimicrobial activity of Mycobacteriophage D29 Lysin B during Mycobacterium ulcerans infection. PLoS Negl. Trop Dis. 2019, 13, e0007113. [CrossRef] [PubMed]

107. Samaddar, S.; Grewal, R.K.; Sinha, S.; Ghosh, S.; Roy, S.; Das Gupta, S.K. Dynamics of Mycobacteriophage-Mycobacterial Host Interaction: Evidence for Secondary Mechanisms for Host Lethality. Appl. Environ. Microbiol. 2016, 82, 124-133. [CrossRef] [PubMed]

108. Van Belleghem, J.D.; Dabrowska, K.; Vaneechoutte, M.; Barr, J.J.; Bollyky, P.L. Interactions between Bacteriophage, Bacteria, and the Mammalian Immune System. Viruses 2018, 11, 10. [CrossRef] [PubMed]

109. Lood, R.; Winer, B.Y.; Pelzek, A.J.; Diez-Martinez, R.; Thandar, M.; Euler, C.W.; Schuch, R.; Fischetti, V.A. Novel phage lysin capable of killing the multidrug-resistant gram-negative bacterium Acinetobacter baumannii in a mouse bacteremia model. Antimicrob. Agents Chemother. 2015, 59, 1983-1991. [CrossRef]

110. Diez-Martinez, R.; De Paz, H.D.; Garcia-Fernandez, E.; Bustamante, N.; Euler, C.W.; Fischetti, V.A.; Menendez, M.; Garcia, P. A novel chimeric phage lysin with high in vitro and in vivo bactericidal activity against Streptococcus pneumoniae. J. Antimicrob. Chemother. 2015, 70, 1763-1773. [CrossRef] [PubMed]

111. Yan, G.; Yang, R.; Fan, K.; Dong, H.; Gao, C.; Wang, S.; Yu, L.; Cheng, Z.; Lei, L. External lysis of Escherichia coli by a bacteriophage endolysin modified with hydrophobic amino acids. AMB Express 2019, 9, 106. [CrossRef]

112. Zampara, A.; Sorensen, M.C.H.; Grimon, D.; Antenucci, F.; Vitt, A.R.; Bortolaia, V.; Briers, Y.; Brondsted, L. Exploiting phage receptor binding proteins to enable endolysins to kill Gram-negative bacteria. Sci. Rep. 2020, 10, 12087. [CrossRef]

113. Dams, D.; Briers, Y. Enzybiotics: Enzyme-Based Antibacterials as Therapeutics. Adv. Exp. Med. Biol. 2019, 1148, $233-253$. [CrossRef] [PubMed]

114. Catalao, M.J.; Filipe, S.R.; Pimentel, M. Revisiting Anti-tuberculosis Therapeutic Strategies That Target the Peptidoglycan Structure and Synthesis. Front. Microbiol. 2019, 10, 190. [CrossRef] [PubMed]

115. Li, Q.; Zhou, M.; Fan, X.; Yan, J.; Li, W.; Xie, J. Mycobacteriophage SWU1 gp39 can potentiate multiple antibiotics against Mycobacterium via altering the cell wall permeability. Sci. Rep. 2016, 6, 28701. [CrossRef] [PubMed]

116. Puiu, M.; Julius, C. Bacteriophage gene products as potential antimicrobials against tuberculosis. Biochem. Soc. Trans. 2019, 47, 847-860. [CrossRef] [PubMed]

117. Singh, S.; Godavarthi, S.; Kumar, A.; Sen, R. A mycobacteriophage genomics approach to identify novel mycobacteriophage proteins with mycobactericidal properties. Microbiology 2019, 165, 722-736. [CrossRef]

118. Yang, Y.; Liu, Z.; He, X.; Yang, J.; Wu, J.; Yang, H.; Li, M.; Qian, Q.; Lai, R.; Xu, W.; et al. A small mycobacteriophage-derived peptide and its improved isomer restrict mycobacterial infection via dual mycobactericidal-immunoregulatory activities. J. Biol. Chem. 2019, 294, 7615-7631. [CrossRef]

119. Casey, E.; van Sinderen, D.; Mahony, J. In Vitro Characteristics of Phages to Guide ‘Real Life' Phage Therapy Suitability. Viruses 2018, 10, 163. [CrossRef] [PubMed]

120. Watanabe, R.; Matsumoto, T.; Sano, G.; Ishii, Y.; Tateda, K.; Sumiyama, Y.; Uchiyama, J.; Sakurai, S.; Matsuzaki, S.; Imai, S.; et al. Efficacy of bacteriophage therapy against gut-derived sepsis caused by Pseudomonas aeruginosa in mice. Antimicrob. Agents Chemother. 2007, 51, 446-452. [CrossRef] [PubMed]

121. Hawkins, C.; Harper, D.; Burch, D.; Anggard, E.; Soothill, J. Topical treatment of Pseudomonas aeruginosa otitis of dogs with a bacteriophage mixture: A before/after clinical trial. Vet. Microbiol. 2010, 146, 309-313. [CrossRef] [PubMed]

122. Saussereau, E.; Debarbieux, L. Bacteriophages in the experimental treatment of Pseudomonas aeruginosa infections in mice. Adv. Virus Res. 2012, 83, 123-141. [CrossRef] [PubMed]

123. Chan, B.K.; Turner, P.E.; Kim, S.; Mojibian, H.R.; Elefteriades, J.A.; Narayan, D. Phage treatment of an aortic graft infected with Pseudomonas aeruginosa. Evol. Med. Public Health 2018, 2018, 60-66. [CrossRef] [PubMed]

124. Jault, P.; Leclerc, T.; Jennes, S.; Pirnay, J.P.; Que, Y.A.; Resch, G.; Rousseau, A.F.; Ravat, F.; Carsin, H.; Le Floch, R.; et al. Efficacy and tolerability of a cocktail of bacteriophages to treat burn wounds infected by Pseudomonas aeruginosa (PhagoBurn): A randomised, controlled, double-blind phase 1/2 trial. Lancet Infect. Dis. 2019, 19, 35-45. [CrossRef]

125. Wills, Q.F.; Kerrigan, C.; Soothill, J.S. Experimental bacteriophage protection against Staphylococcus aureus abscesses in a rabbit model. Antimicrob. Agents Chemother. 2005, 49, 1220-1221. [CrossRef] [PubMed]

126. Chhibber, S.; Kaur, S.; Kumari, S. Therapeutic potential of bacteriophage in treating Klebsiella pneumoniae B5055-mediated lobar pneumonia in mice. J. Med. Microbiol. 2008, 57, 1508-1513. [CrossRef] [PubMed]

127. Soothill, J.S. Treatment of experimental infections of mice with bacteriophages. J. Med. Microbiol. 1992, 37, 258-261. [CrossRef] 
128. Nale, J.Y.; Spencer, J.; Hargreaves, K.R.; Buckley, A.M.; Trzepinski, P.; Douce, G.R.; Clokie, M.R.J. Bacteriophage Combinations Significantly Reduce Clostridium difficile Growth In Vitro and Proliferation In Vivo. Antimicrob. Agents Chemother. 2016, 60, 968-981. [CrossRef] [PubMed]

129. Duan, Y.; Llorente, C.; Lang, S.; Brandl, K.; Chu, H.; Jiang, L.; White, R.C.; Clarke, T.H.; Nguyen, K.; Torralba, M.; et al. Bacteriophage targeting of gut bacterium attenuates alcoholic liver disease. Nature 2019, 575, 505-511. [CrossRef]

130. Sheng, H.; Knecht, H.J.; Kudva, I.T.; Hovde, C.J. Application of bacteriophages to control intestinal Escherichia coli O157:H7 levels in ruminants. Appl. Environ. Microbiol. 2006, 72, 5359-5366. [CrossRef] [PubMed]

131. Cislo, M.; Dabrowski, M.; Weber-Dabrowska, B.; Woyton, A. Bacteriophage treatment of suppurative skin infections. Arch. Immunol. Ther. Exp. 1987, 35, 175-183.

132. Principi, N.; Silvestri, E.; Esposito, S. Advantages and Limitations of Bacteriophages for the Treatment of Bacterial Infections. Front. Pharmacol. 2019, 10, 513. [CrossRef] [PubMed]

133. Hill, C.; Mills, S.; Ross, R.P. Phages \& antibiotic resistance: Are the most abundant entities on earth ready for a comeback? Future Microbiol. 2018, 13, 711-726. [CrossRef] [PubMed]

134. Fish, R.; Kutter, E.; Wheat, G.; Blasdel, B.; Kutateladze, M.; Kuhl, S. Bacteriophage treatment of intransigent diabetic toe ulcers: A case series. J. Wound Care 2016, 25, S27-S33. [CrossRef]

135. Wright, A.; Hawkins, C.H.; Anggard, E.E.; Harper, D.R. A controlled clinical trial of a therapeutic bacteriophage preparation in chronic otitis due to antibiotic-resistant Pseudomonas aeruginosa; a preliminary report of efficacy. Clin. Otolaryngol. 2009, 34, 349-357. [CrossRef]

136. Jun, J.W.; Shin, T.H.; Kim, J.H.; Shin, S.P.; Han, J.E.; Heo, G.J.; De Zoysa, M.; Shin, G.W.; Chai, J.Y.; Park, S.C. Bacteriophage therapy of a Vibrio parahaemolyticus infection caused by a multiple-antibiotic-resistant O3:K6 pandemic clinical strain. J. Infect. Dis. 2014, 210, 72-78. [CrossRef] [PubMed]

137. Chan, B.K.; Sistrom, M.; Wertz, J.E.; Kortright, K.E.; Narayan, D.; Turner, P.E. Phage selection restores antibiotic sensitivity in MDR Pseudomonas aeruginosa. Sci. Rep. 2016, 6, 26717. [CrossRef] [PubMed]

138. Azimi, T.; Mosadegh, M.; Nasiri, M.J.; Sabour, S.; Karimaei, S.; Nasser, A. Phage therapy as a renewed therapeutic approach to mycobacterial infections: A comprehensive review. Infect. Drug Resist. 2019, 12, 2943-2959. [CrossRef] [PubMed]

139. Sula, L.; Sulova, J.; Stolcpartova, M. Therapy of experimental tuberculosis in guinea pigs with mycobacterial phages DS-6A, GR-21 T, My-327. Czech. Med. 1981, 4, 209-214. [PubMed]

140. Peng, L.; Luo, Y.; Chen, B.; Li, Y.; Shen, X.; Su, C.; Wang, G. Therapeutic effect of bacteriophage D29 in the treatment for guinea pigs infected with sensitive strain of Mycobacterium tuberculosis. Chin. J. Zoonoses 2009, 25, 733-736.

141. Gordillo Altamirano, F.L.; Barr, J.J. Phage Therapy in the Postantibiotic Era. Clin. Microbiol. Rev. 2019, 32. [CrossRef]

142. Ooi, M.L.; Drilling, A.J.; Morales, S.; Fong, S.; Moraitis, S.; Macias-Valle, L.; Vreugde, S.; Psaltis, A.J.; Wormald, P.J. Safety and Tolerability of Bacteriophage Therapy for Chronic Rhinosinusitis Due to Staphylococcus aureus. JAMA Otolaryngol. 2019, 145, 723-729. [CrossRef] [PubMed]

143. Bogovazova, G.G.; Voroshilova, N.N.; Bondarenko, V.M. The efficacy of Klebsiella pneumoniae bacteriophage in the therapy of experimental Klebsiella infection. Zh. Mikrobiol. Epidemiol. Immunobiol. 1991, 5-8.

144. Aziz, R.K.; Dwivedi, B.; Akhter, S.; Breitbart, M.; Edwards, R.A. Multidimensional metrics for estimating phage abundance, distribution, gene density, and sequence coverage in metagenomes. Front. Microbiol. 2015, 6, 381. [CrossRef]

145. Hatfull, G.F. Bacteriophage genomics. Curr. Opin. Microbiol. 2008, 11, 447-453. [CrossRef]

146. Endersen, L.; Coffey, A.; Neve, H.; McAuliffe, O.; Ross, R.P.; O'Mahony, J.M. Isolation and characterisation of six novel mycobacteriophages and investigation of their antimicrobial potential in milk. Int. Dairy J. 2013, 28, 8-14. [CrossRef]

147. Caratenuto, R.A., 3rd; Ciabattoni, G.O.; DesGranges, N.J.; Drost, C.L.; Gao, L.; Gipson, B.; Kahler, N.C.; Kirven, N.A.; Melehani, J.C.; Patel, K.; et al. Genome Sequences of Six Cluster N Mycobacteriophages, Kevin1, Nenae, Parmesanjohn, ShrimpFriedEgg, Smurph, and SpongeBob, Isolated on Mycobacterium smegmatis mc(2)155. Microbiol. Resour. Announc. 2019, 8. [CrossRef] [PubMed]

148. Levin, B.R.; Bull, J.J. Phage therapy revisited: The population biology of a bacterial infection and its treatment with bacteriophage and antibiotics. Am. Nat. 1996, 147, 881-898. [CrossRef]

149. Young, R.; Gill, J.J. MICROBIOLOGY. Phage therapy redux-What is to be done? Science 2015, 350, 1163-1164. [CrossRef]

150. Dedrick, R.M.; Guerrero Bustamante, C.A.; Garlena, R.A.; Pinches, R.S.; Cornely, K.; Hatfull, G.F. Mycobacteriophage ZoeJ: A broad host-range close relative of mycobacteriophage TM4. Tuberculosis 2019, 115, 14-23. [CrossRef] [PubMed]

151. Mayer, O.; Jain, P.; Weisbrod, T.R.; Biro, D.; Ho, L.; Jacobs-Sera, D.; Hatfull, G.F.; Jacobs, W.R., Jr. Fluorescent Reporter DS6A Mycobacteriophages Reveal Unique Variations in Infectibility and Phage Production in Mycobacteria. J. Bacteriol. 2016, 198, 3220-3232. [CrossRef] [PubMed]

152. Rybniker, J.; Kramme, S.; Small, P.L. Host range of 14 mycobacteriophages in Mycobacterium ulcerans and seven other mycobacteria including Mycobacterium tuberculosis-Application for identification and susceptibility testing. J. Med. Microbiol. 2006, 55, 37-42. [CrossRef]

153. Lapenkova, M.B.; Smirnova, N.S.; Rutkevich, P.N.; Vladimirsky, M.A. Evaluation of the Efficiency of Lytic Mycobacteriophage D29 on the Model of M. tuberculosis-Infected Macrophage RAW 264 Cell Line. Bull. Exp. Biol. Med. 2018, 164, 344-346. [CrossRef] [PubMed] 
154. Carrigy, N.B.; Larsen, S.E.; Reese, V.; Pecor, T.; Harrison, M.; Kuehl, P.J.; Hatfull, G.F.; Sauvageau, D.; Baldwin, S.L.; Finlay, W.H.; et al. Prophylaxis of Mycobacterium tuberculosis H37Rv Infection in a Preclinical Mouse Model via Inhalation of Nebulized Bacteriophage D29. Antimicrob. Agents Chemother. 2019, 63. [CrossRef]

155. Liu, K.Y.; Yang, W.H.; Dong, X.K.; Cong, L.M.; Li, N.; Li, Y.; Wen, Z.B.; Yin, Z.; Lan, Z.J.; Li, W.P.; et al. Inhalation Study of Mycobacteriophage D29 Aerosol for Mice by Endotracheal Route and Nose-Only Exposure. J. Aerosol. Med. Pulm. Drug Deliv. 2016, 29, 393-405. [CrossRef]

156. Jacobs-Sera, D.; Marinelli, L.J.; Bowman, C.; Broussard, G.W.; Guerrero Bustamante, C.; Boyle, M.M.; Petrova, Z.O.; Dedrick, R.M.; Pope, W.H.; (SEA-PHAGES) program; et al. On the nature of mycobacteriophage diversity and host preference. Virology 2012, 434, 187-201. [CrossRef] [PubMed]

157. Morris, S.A. Genetic Diversity of Mycobacteriophages and the Unique Abilities of Cluster K. Corinthian $2017,1,5$.

158. de Jonge, P.A.; Nobrega, F.L.; Brouns, S.J.J.; Dutilh, B.E. Molecular and Evolutionary Determinants of Bacteriophage Host Range. Trends Microbiol. 2019, 27, 51-63. [CrossRef]

159. Shao, Y.; Wang, I.N. Bacteriophage adsorption rate and optimal lysis time. Genetics 2008, 180, 471-482. [CrossRef]

160. Cebria-Mendoza, M.; Sanjuan, R.; Domingo-Calap, P. Directed Evolution of a Mycobacteriophage. Antibiotics $2019,8,46$. [CrossRef] [PubMed]

161. Chen, J.; Kriakov, J.; Singh, A.; Jacobs, W.R., Jr.; Besra, G.S.; Bhatt, A. Defects in glycopeptidolipid biosynthesis confer phage I3 resistance in Mycobacterium smegmatis. Microbiology 2009, 155, 4050-4057. [CrossRef] [PubMed]

162. Furuchi, A.; Tokunaga, T. Nature of the receptor substance of Mycobacterium smegmatis for D4 bacteriophage adsorption. J. Bacteriol. 1972, 111, 404-411. [CrossRef]

163. Khoo, K.H.; Suzuki, R.; Dell, A.; Morris, H.R.; McNeil, M.R.; Brennan, P.J.; Besra, G.S. Chemistry of the lyxose-containing mycobacteriophage receptors of Mycobacterium phlei/Mycobacterium smegmatis. Biochemistry 1996, 35, 11812-11819. [CrossRef] [PubMed]

164. Sassi, M.; Bebeacua, C.; Drancourt, M.; Cambillau, C. The first structure of a mycobacteriophage, the Mycobacterium abscessus subsp. bolletii phage Araucaria. J. Virol. 2013, 87, 8099-8109. [CrossRef]

165. Arutyunov, D.; Singh, U.; El-Hawiet, A.; Seckler, H.D.; Nikjah, S.; Joe, M.; Bai, Y.; Lowary, T.L.; Klassen, J.S.; Evoy, S.; et al. Mycobacteriophage cell binding proteins for the capture of mycobacteria. Bacteriophage 2014, 4, e960346. [CrossRef] [PubMed]

166. Kortright, K.E.; Chan, B.K.; Turner, P.E. High-throughput discovery of phage receptors using transposon insertion sequencing of bacteria. Proc. Natl. Acad. Sci. USA 2020, 117, 18670-18679. [CrossRef] [PubMed]

167. Vilcheze, C.; Copeland, J.; Keiser, T.L.; Weisbrod, T.; Washington, J.; Jain, P.; Malek, A.; Weinrick, B.; Jacobs, W.R., Jr. Rational Design of Biosafety Level 2-Approved, Multidrug-Resistant Strains of Mycobacterium tuberculosis through Nutrient Auxotrophy. mBio 2018, 9. [CrossRef] [PubMed]

168. Dunne, M.; Rupf, B.; Tala, M.; Qabrati, X.; Ernst, P.; Shen, Y.; Sumrall, E.; Heeb, L.; Pluckthun, A.; Loessner, M.J.; et al. Reprogramming Bacteriophage Host Range through Structure-Guided Design of Chimeric Receptor Binding Proteins. Cell Rep. 2019, 29, 1336-1350.e4. [CrossRef] [PubMed]

169. Brabban, A.D.; Hite, E.; Callaway, T.R. Evolution of foodborne pathogens via temperate bacteriophage-mediated gene transfer. Foodborne Pathog. Dis. 2005, 2, 287-303. [CrossRef] [PubMed]

170. Haaber, J.; Leisner, J.J.; Cohn, M.T.; Catalan-Moreno, A.; Nielsen, J.B.; Westh, H.; Penades, J.R.; Ingmer, H. Bacterial viruses enable their host to acquire antibiotic resistance genes from neighbouring cells. Nat. Commun. 2016, 7, 13333. [CrossRef]

171. Sweere, J.M.; Van Belleghem, J.D.; Ishak, H.; Bach, M.S.; Popescu, M.; Sunkari, V.; Kaber, G.; Manasherob, R.; Suh, G.A.; Cao, X.; et al. Bacteriophage trigger antiviral immunity and prevent clearance of bacterial infection. Science 2019, 363. [CrossRef] [PubMed]

172. Scordo, J.M.; Olmo-Fontanez, A.M.; Kelley, H.V.; Sidiki, S.; Arcos, J.; Akhter, A.; Wewers, M.D.; Torrelles, J.B. The human lung mucosa drives differential Mycobacterium tuberculosis infection outcome in the alveolar epithelium. Mucosal. Immunol. 2019, 12, 795-804. [CrossRef]

173. Arcos, J.; Sasindran, S.J.; Moliva, J.I.; Scordo, J.M.; Sidiki, S.; Guo, H.; Venigalla, P.; Kelley, H.V.; Lin, G.; Diangelo, L.; et al. Mycobacterium tuberculosis cell wall released fragments by the action of the human lung mucosa modulate macrophages to control infection in an IL-10-dependent manner. Mucosal. Immunol. 2017, 10, 1248-1258. [CrossRef]

174. Moliva, J.I.; Duncan, M.A.; Olmo-Fontanez, A.; Akhter, A.; Arnett, E.; Scordo, J.M.; Ault, R.; Sasindran, S.J.; Azad, A.K.; Montoya, M.J.; et al. The Lung Mucosa Environment in the Elderly Increases Host Susceptibility to Mycobacterium tuberculosis Infection. J. Infect. Dis. 2019, 220, 514-523. [CrossRef]

175. Moliva, J.I.; Hossfeld, A.P.; Canan, C.H.; Dwivedi, V.; Wewers, M.D.; Beamer, G.; Turner, J.; Torrelles, J.B. Exposure to human alveolar lining fluid enhances Mycobacterium bovis BCG vaccine efficacy against Mycobacterium tuberculosis infection in a CD8(+) T-cell-dependent manner. Mucosal. Immunol. 2018, 11, 968-978. [CrossRef]

176. Ehlers, S.; Schaible, U.E. The granuloma in tuberculosis: Dynamics of a host-pathogen collusion. Front. Immunol. 2012, 3, 411. [CrossRef]

177. Serafini, A.; Tan, L.; Horswell, S.; Howell, S.; Greenwood, D.J.; Hunt, D.M.; Phan, M.D.; Schembri, M.; Monteleone, M.; Montague, C.R.; et al. Mycobacterium tuberculosis requires glyoxylate shunt and reverse methylcitrate cycle for lactate and pyruvate metabolism. Mol. Microbiol. 2019, 112, 1284-1307. [CrossRef]

178. Bell, L.C.K.; Noursadeghi, M. Pathogenesis of HIV-1 and Mycobacterium tuberculosis co-infection. Nat. Rev. Microbiol. 2018, 16, 80-90. [CrossRef] [PubMed] 
179. Segura-Cerda, C.A.; Lopez-Romero, W.; Flores-Valdez, M.A. Changes in Host Response to Mycobacterium tuberculosis Infection Associated With Type 2 Diabetes: Beyond Hyperglycemia. Front. Cell Infect. Microbiol. 2019, 9, 342. [CrossRef]

180. Zykov, M.P.; Donets Iu, I.; Godovannyi, B.A. A study of the phage lysability of mycobacteria isolated in Africa. Zh Mikrobiol Epidemiol. Immunobiol. 1966, 43, 74-80.

181. Rodriguez, D.C.; Ocampo, M.; Salazar, L.M.; Patarroyo, M.A. Quantifying intracellular Mycobacterium tuberculosis: An essential issue for in vitro assays. Microbiologyopen 2018, 7, e00588. [CrossRef] [PubMed]

182. Nguyen, S.; Baker, K.; Padman, B.S.; Patwa, R.; Dunstan, R.A.; Weston, T.A.; Schlosser, K.; Bailey, B.; Lithgow, T.; Lazarou, M.; et al. Bacteriophage Transcytosis Provides a Mechanism To Cross Epithelial Cell Layers. mBio 2017, 8. [CrossRef] [PubMed]

183. Morello, E.; Saussereau, E.; Maura, D.; Huerre, M.; Touqui, L.; Debarbieux, L. Pulmonary bacteriophage therapy on Pseudomonas aeruginosa cystic fibrosis strains: First steps towards treatment and prevention. PLoS ONE 2011, 6, e16963. [CrossRef] [PubMed]

184. Kaur, S.; Harjai, K.; Chhibber, S. Bacteriophage-aided intracellular killing of engulfed methicillin-resistant Staphylococcus aureus (MRSA) by murine macrophages. Appl. Microbiol. Biotechnol. 2014, 98, 4653-4661. [CrossRef]

185. Broxmeyer, L.; Sosnowska, D.; Miltner, E.; Chacon, O.; Wagner, D.; McGarvey, J.; Barletta, R.G.; Bermudez, L.E. Killing of Mycobacterium avium and Mycobacterium tuberculosis by a mycobacteriophage delivered by a nonvirulent mycobacterium: A model for phage therapy of intracellular bacterial pathogens. J. Infect. Dis. 2002, 186, 1155-1160. [CrossRef] [PubMed]

186. Danelishvili, L.; Young, L.S.; Bermudez, L.E. In vivo efficacy of phage therapy for Mycobacterium avium infection as delivered by a nonvirulent mycobacterium. Microb. Drug Resist. 2006, 12, 1-6. [CrossRef] [PubMed]

187. Sweeney, K.A.; Dao, D.N.; Goldberg, M.F.; Hsu, T.; Venkataswamy, M.M.; Henao-Tamayo, M.; Ordway, D.; Sellers, R.S.; Jain, P.; Chen, B.; et al. A recombinant Mycobacterium smegmatis induces potent bactericidal immunity against Mycobacterium tuberculosis. Nat. Med. 2011, 17, 1261-1268. [CrossRef]

188. Nieth, A.; Verseux, C.; Barnert, S.; Suss, R.; Romer, W. A first step toward liposome-mediated intracellular bacteriophage therapy. Expert Opin. Drug Deliv. 2015, 12, 1411-1424. [CrossRef] [PubMed]

189. Di Giovine, M.; Salone, B.; Martina, Y.; Amati, V.; Zambruno, G.; Cundari, E.; Failla, C.M.; Saggio, I. Binding properties, cell delivery, and gene transfer of adenoviral penton base displaying bacteriophage. Virology 2001, 282, 102-112. [CrossRef] [PubMed]

190. Pontow, S.E.; Kery, V.; Stahl, P.D. Mannose receptor. Int. Rev. Cytol. 1992, 137B, 221-244. [CrossRef]

191. Astarie-Dequeker, C.; N’Diaye, E.N.; Le Cabec, V.; Rittig, M.G.; Prandi, J.; Maridonneau-Parini, I. The mannose receptor mediates uptake of pathogenic and nonpathogenic mycobacteria and bypasses bactericidal responses in human macrophages. Infect. Immun. 1999, 67, 469-477. [CrossRef] [PubMed]

192. Piuri, M.; Rondon, L.; Urdaniz, E.; Hatfull, G.F. Generation of affinity-tagged fluoromycobacteriophages by mixed assembly of phage capsids. Appl. Environ. Microbiol. 2013, 79, 5608-5615. [CrossRef] [PubMed]

193. Rohde, C.; Resch, G.; Pirnay, J.P.; Blasdel, B.G.; Debarbieux, L.; Gelman, D.; Gorski, A.; Hazan, R.; Huys, I.; Kakabadze, E.; et al. Expert Opinion on Three Phage Therapy Related Topics: Bacterial Phage Resistance, Phage Training and Prophages in Bacterial Production Strains. Viruses 2018, 10, 178. [CrossRef]

194. Kim, J.S. Microbial warfare against viruses. Science 2018, 359, 993. [CrossRef]

195. Seed, K.D. Battling Phages: How Bacteria Defend against Viral Attack. PLoS Pathog 2015, 11. [CrossRef] [PubMed]

196. Labrie, S.J.; Samson, J.E.; Moineau, S. Bacteriophage resistance mechanisms. Nat. Rev. Microbiol. 2010, 8, 317-327. [CrossRef] [PubMed]

197. Hampton, H.G.; Watson, B.N.J.; Fineran, P.C. The arms race between bacteria and their phage foes. Nature 2020, 577, 327-336. [CrossRef] [PubMed]

198. Maxwell, K.L. Phages Fight Back: Inactivation of the CRISPR-Cas Bacterial Immune System by Anti-CRISPR Proteins. PLoS Pathog 2016, 12, e1005282. [CrossRef] [PubMed]

199. Goldfarb, T.; Sberro, H.; Weinstock, E.; Cohen, O.; Doron, S.; Charpak-Amikam, Y.; Afik, S.; Ofir, G.; Sorek, R. BREX is a novel phage resistance system widespread in microbial genomes. Embo J. 2015, 34, 169-183. [CrossRef] [PubMed]

200. Ofir, G.; Melamed, S.; Sberro, H.; Mukamel, Z.; Silverman, S.; Yaakov, G.; Doron, S.; Sorek, R. DISARM is a widespread bacterial defence system with broad anti-phage activities. Nat. Microbiol. 2018, 3. [CrossRef] [PubMed]

201. Torres-Barcelo, C. Phage Therapy Faces Evolutionary Challenges. Viruses 2018, 10, 323. [CrossRef] [PubMed]

202. Nguyen, Q.H.; Contamin, L.; Nguyen, T.V.A.; Banuls, A.L. Insights into the processes that drive the evolution of drug resistance in Mycobacterium tuberculosis. Evol. Appl. 2018, 11, 1498-1511. [CrossRef] [PubMed]

203. Capparelli, R.; Nocerino, N.; Lanzetta, R.; Silipo, A.; Amoresano, A.; Giangrande, C.; Becker, K.; Blaiotta, G.; Evidente, A.; Cimmino, A.; et al. Bacteriophage-resistant Staphylococcus aureus mutant confers broad immunity against staphylococcal infection in mice. PLOS ONE 2010, 5, e11720. [CrossRef] [PubMed]

204. Evans, T.J.; Trauner, A.; Komitopoulou, E.; Salmond, G.P. Exploitation of a new flagellatropic phage of Erwinia for positive selection of bacterial mutants attenuated in plant virulence: Towards phage therapy. J. Appl. Microbiol. 2010, 108, 676-685. [CrossRef]

205. Wright, R.C.T.; Friman, V.P.; Smith, M.C.M.; Brockhurst, M.A. Cross-resistance is modular in bacteria-phage interactions. PLoS Biol. 2018, 16. [CrossRef] [PubMed]

206. Hall, A.R.; De Vos, D.; Friman, V.P.; Pirnay, J.P.; Buckling, A. Effects of sequential and simultaneous applications of bacteriophages on populations of Pseudomonas aeruginosa in vitro and in wax moth larvae. Appl. Environ. Microbiol. 2012, 78, 5646-5652. [CrossRef]

207. Chaudhry, W.N.; Concepcion-Acevedo, J.; Park, T.; Andleeb, S.; Bull, J.J.; Levin, B.R. Synergy and Order Effects of Antibiotics and Phages in Killing Pseudomonas aeruginosa Biofilms. PLoS ONE 2017, 12, e0168615. [CrossRef] [PubMed] 
208. Torres-Barcelo, C.; Hochberg, M.E. Evolutionary Rationale for Phases as Complements of Antibiotics. Trends Microbiol. 2016, 24, 249-256. [CrossRef] [PubMed]

209. Oechslin, F.; Piccardi, P.; Mancini, S.; Gabard, J.; Moreillon, P.; Entenza, J.M.; Resch, G.; Que, Y.A. Synergistic Interaction Between Phage Therapy and Antibiotics Clears Pseudomonas Aeruginosa Infection in Endocarditis and Reduces Virulence. J. Infect. Dis. 2017, 215, 703-712. [CrossRef] [PubMed]

210. Zhang, Q.G.; Buckling, A. Phages limit the evolution of bacterial antibiotic resistance in experimental microcosms. Evol. Appl. 2012, 5, 575-582. [CrossRef]

211. Ryan, E.M.; Alkawareek, M.Y.; Donnelly, R.F.; Gilmore, B.F. Synergistic phage-antibiotic combinations for the control of Escherichia coli biofilms in vitro. FEMS Immunol. Med. Microbiol. 2012, 65, 395-398. [CrossRef] [PubMed]

212. Cairns, J.; Becks, L.; Jalasvuori, M.; Hiltunen, T. Sublethal streptomycin concentrations and lytic bacteriophage together promote resistance evolution. Philos. Trans. R. Soc. Lond. B Biol. Sci. 2017, 372. [CrossRef] [PubMed]

213. Kamal, F.; Dennis, J.J. Burkholderia cepacia complex Phage-Antibiotic Synergy (PAS): Antibiotics stimulate lytic phage activity. Appl. Environ. Microbiol. 2015, 81, 1132-1138. [CrossRef] [PubMed]

214. Trasta, A. Personalized medicine and proper dosage: Over- and undertreatment of chronic diseases endanger patients' health and strain public health systems. EMBO Rep. 2018, 19. [CrossRef]

215. Graham, F.; Hatfull, R.V. Respirable Bacteriophage Aerosols for the Prevention and Treatment of Tuberculosis. In Drug Delivery Systems for Tuberculosis Prevention and Treatment; Hickey, A.J., Ed.; John Wiley \& Sons, Ltd.: Hoboken, NJ, USA, 2016.

216. Pride, D.T.; Salzman, J.; Haynes, M.; Rohwer, F.; Davis-Long, C.; White, R.A.; Loomer, P.; Armitage, G.C.; Relman, D.A. Evidence of a robust resident bacteriophage population revealed through analysis of the human salivary virome. ISME J. 2012, 6, 915-926. [CrossRef] [PubMed]

217. Santiago-Rodriguez, T.M.; Ly, M.; Bonilla, N.; Pride, D.T. The human urine virome in association with urinary tract infections. Front. Microbiol. 2015, 6, 14. [CrossRef] [PubMed]

218. Navarro, F.; Muniesa, M. Phages in the Human Body. Front. Microbiol. 2017, 8, 566. [CrossRef]

219. Lim, E.S.; Zhou, Y.; Zhao, G.; Bauer, I.K.; Droit, L.; Ndao, I.M.; Warner, B.B.; Tarr, P.I.; Wang, D.; Holtz, L.R. Early life dynamics of the human gut virome and bacterial microbiome in infants. Nat. Med. 2015, 21, 1228-1234. [CrossRef] [PubMed]

220. Lim, Y.W.; Schmieder, R.; Haynes, M.; Willner, D.; Furlan, M.; Youle, M.; Abbott, K.; Edwards, R.; Evangelista, J.; Conrad, D.; et al. Metagenomics and metatranscriptomics: Windows on CF-associated viral and microbial communities. J. Cyst. Fibros. 2013, 12, 154-164. [CrossRef] [PubMed]

221. Krut, O.; Bekeredjian-Ding, I. Contribution of the Immune Response to Phage Therapy. J. Immunol. 2018, 200, 3037-3044. [CrossRef] [PubMed]

222. Barr, J.J.; Auro, R.; Furlan, M.; Whiteson, K.L.; Erb, M.L.; Pogliano, J.; Stotland, A.; Wolkowicz, R.; Cutting, A.S.; Doran, K.S.; et al. Bacteriophage adhering to mucus provide a non-host-derived immunity. Proc. Natl. Acad. Sci. USA 2013, 110, 10771-10776. [CrossRef] [PubMed]

223. Fraser, J.S.; Yu, Z.; Maxwell, K.L.; Davidson, A.R. Ig-like domains on bacteriophages: A tale of promiscuity and deceit. J. Mol. Biol. 2006, 359, 496-507. [CrossRef] [PubMed]

224. Pope, W.H.; Jacobs-Sera, D.; Russell, D.A.; Peebles, C.L.; Al-Atrache, Z.; Alcoser, T.A.; Alexander, L.M.; Alfano, M.B.; Alford, S.T.; Amy, N.E.; et al. Expanding the diversity of mycobacteriophages: Insights into genome architecture and evolution. PLoS ONE 2011, 6, e16329. [CrossRef] [PubMed]

225. Abedon, S.T. Phage therapy of pulmonary infections. Bacteriophage 2015, 5, e1020260. [CrossRef] [PubMed]

226. Levin, B.R.; Bull, J.J. Population and evolutionary dynamics of phage therapy. Nat. Rev. Microbiol. 2004, 2, 166-173. [CrossRef] [PubMed]

227. Malik, D.J.; Sokolov, I.J.; Vinner, G.K.; Mancuso, F.; Cinquerrui, S.; Vladisavljevic, G.T.; Clokie, M.R.J.; Garton, N.J.; Stapley, A.G.F.; Kirpichnikova, A. Formulation, stabilisation and encapsulation of bacteriophage for phage therapy. Adv. Colloid Interface Sci. 2017, 249, 100-133. [CrossRef]

228. Huh, H.; Wong, S.; St Jean, J.; Slavcev, R. Bacteriophage interactions with mammalian tissue: Therapeutic applications. Adv. Drug Deliv. Rev. 2019, 145, 4-17. [CrossRef] [PubMed]

229. Dabrowska, K. Phage therapy: What factors shape phage pharmacokinetics and bioavailability? Systematic and critical review. Med. Res. Rev. 2019, 39, 2000-2025. [CrossRef] [PubMed]

230. Carrigy, N.B.; Chang, R.Y.; Leung, S.S.Y.; Harrison, M.; Petrova, Z.; Pope, W.H.; Hatfull, G.F.; Britton, W.J.; Chan, H.K.; Sauvageau, D.; et al. Anti-Tuberculosis Bacteriophage D29 Delivery with a Vibrating Mesh Nebulizer, Jet Nebulizer, and Soft Mist Inhaler. Pharm. Res. 2017, 34, 2084-2096. [CrossRef] [PubMed]

231. Jonczyk-Matysiak, E.; Weber-Dabrowska, B.; Owczarek, B.; Miedzybrodzki, R.; Lusiak-Szelachowska, M.; Lodej, N.; Gorski, A. Phage-Phagocyte Interactions and Their Implications for Phage Application as Therapeutics. Viruses 2017, 9, 150. [CrossRef]

232. Dabrowska, K.; Miernikiewicz, P.; Piotrowicz, A.; Hodyra, K.; Owczarek, B.; Lecion, D.; Kazmierczak, Z.; Letarov, A.; Gorski, A. Immunogenicity studies of proteins forming the T4 phage head surface. J. Virol. 2014, 88, 12551-12557. [CrossRef] [PubMed]

233. Miedzybrodzki, R.; Borysowski, J.; Klak, M.; Jonczyk-Matysiak, E.; Obminska-Mrukowicz, B.; Suszko-Pawlowska, A.; Bubak, B.; Weber-Dabrowska, B.; Gorski, A. In Vivo Studies on the Influence of Bacteriophage Preparations on the Autoimmune Inflammatory Process. Biomed Res. Int. 2017, 2017, 3612015. [CrossRef] 
234. Hodyra-Stefaniak, K.; Miernikiewicz, P.; Drapala, J.; Drab, M.; Jonczyk-Matysiak, E.; Lecion, D.; Kazmierczak, Z.; Beta, W.; Majewska, J.; Harhala, M.; et al. Mammalian Host-Versus-Phage immune response determines phage fate in vivo. Sci. Rep. 2015, 5, 14802. [CrossRef]

235. Singla, S.; Harjai, K.; Katare, O.P.; Chhibber, S. Encapsulation of Bacteriophage in Liposome Accentuates Its Entry in to Macrophage and Shields It from Neutralizing Antibodies. PLoS ONE 2016, 11, e0153777. [CrossRef]

236. Vandenheuvel, D.; Lavigne, R.; Brussow, H. Bacteriophage Therapy: Advances in Formulation Strategies and Human Clinical Trials. Annu. Rev. Virol. 2015, 2, 599-618. [CrossRef] [PubMed]

237. Chang, R.Y.K.; Wallin, M.; Lin, Y.; Leung, S.S.Y.; Wang, H.; Morales, S.; Chan, H.K. Phage therapy for respiratory infections. Adv. Drug Deliv. Rev. 2018, 133, 76-86. [CrossRef] [PubMed]

238. Hanif, S.N.; Garcia-Contreras, L. Pharmaceutical aerosols for the treatment and prevention of tuberculosis. Front. Cell Infect. Microbiol. 2012, 2, 118. [CrossRef]

239. Roach, D.R.; Leung, C.Y.; Henry, M.; Morello, E.; Singh, D.; Di Santo, J.P.; Weitz, J.S.; Debarbieux, L. Synergy between the Host Immune System and Bacteriophage Is Essential for Successful Phage Therapy against an Acute Respiratory Pathogen. Cell Host Microbe 2017, 22, 38-47.e4. [CrossRef] [PubMed]

240. Van Belleghem, J.D.; Clement, F.; Merabishvili, M.; Lavigne, R.; Vaneechoutte, M. Pro- and anti-inflammatory responses of peripheral blood mononuclear cells induced by Staphylococcus aureus and Pseudomonas aeruginosa phages. Sci. Rep. 2017, 7, 8004. [CrossRef] [PubMed]

241. Gogokhia, L.; Buhrke, K.; Bell, R.; Hoffman, B.; Brown, D.G.; Hanke-Gogokhia, C.; Ajami, N.J.; Wong, M.C.; Ghazaryan, A.; Valentine, J.F.; et al. Expansion of Bacteriophages Is Linked to Aggravated Intestinal Inflammation and Colitis. Cell Host Microbe 2019, 25, 285-299.e8. [CrossRef] [PubMed]

242. Xiong, X.; Zhang, H.M.; Wu, T.T.; Xu, L.; Gan, Y.L.; Jiang, L.S.; Zhang, L.; Guo, S.L. Titer dynamic analysis of D29 within MTB-infected macrophages and effect on immune function of macrophages. Exp. Lung Res. 2014, 40, 86-98. [CrossRef] [PubMed]

243. Sarker, S.A.; McCallin, S.; Barretto, C.; Berger, B.; Pittet, A.C.; Sultana, S.; Krause, L.; Huq, S.; Bibiloni, R.; Bruttin, A.; et al. Oral T4-like phage cocktail application to healthy adult volunteers from Bangladesh. Virology 2012, 434, 222-232. [CrossRef] [PubMed]

244. Petrovic Fabijan, A.; Lin, R.C.Y.; Ho, J.; Maddocks, S.; Ben Zakour, N.L.; Iredell, J.R.; Westmead Bacteriophage Therapy Team. Safety of bacteriophage therapy in severe Staphylococcus aureus infection. Nat. Microbiol. 2020. [CrossRef] [PubMed]

245. Pelfrene, E.; Willebrand, E.; Cavaleiro Sanches, A.; Sebris, Z.; Cavaleri, M. Bacteriophage therapy: A regulatory perspective. J. Antimicrob. Chemother. 2016, 71, 2071-2074. [CrossRef] [PubMed]

246. Peng, H.; Borg, R.E.; Dow, L.P.; Pruitt, B.L.; Chen, I.A. Controlled phage therapy by photothermal ablation of specific bacterial species using gold nanorods targeted by chimeric phages. Proc. Natl. Acad. Sci. USA 2020, 117, 1951-1961. [CrossRef] [PubMed]

247. Luong, T.; Salabarria, A.C.; Edwards, R.A.; Roach, D.R. Standardized bacteriophage purification for personalized phage therapy. Nat. Protoc. 2020, 15, 2867-2890. [CrossRef] [PubMed] 